Florida International University

FIU Digital Commons

FIU Electronic Theses and Dissertations

University Graduate School

$7-2-2020$

\title{
Much Ado About Contemporary Women: Gender Adapted in Contemporary Settings
}

Jessica C. Valdes

Florida International University, jvald057@fiu.edu

Follow this and additional works at: https://digitalcommons.fiu.edu/etd

Part of the Digital Humanities Commons, Dramatic Literature, Criticism and Theory Commons, Literature in English, British Isles Commons, Other Film and Media Studies Commons, Performance Studies Commons, and the Women's Studies Commons

\section{Recommended Citation}

Valdes, Jessica C., "Much Ado About Contemporary Women: Gender Adapted in Contemporary Settings" (2020). FIU Electronic Theses and Dissertations. 4472.

https://digitalcommons.fiu.edu/etd/4472

This work is brought to you for free and open access by the University Graduate School at FIU Digital Commons. It has been accepted for inclusion in FIU Electronic Theses and Dissertations by an authorized administrator of FIU Digital Commons. For more information, please contact dcc@fiu.edu. 
FLORIDA INTERNATIONAL UNIVERSITY

Miami, Florida

MUCH ADO ABOUT CONTEMPORARY WOMEN:

GENDER ADAPTED IN CONTEMPORARY SETTINGS

\author{
A thesis submitted in partial fulfillment of the \\ requirements for the degree of \\ MASTER OF ARTS \\ in \\ ENGLISH \\ by \\ Jessica C. Valdes
}

2020 
To: Dean Michael R. Heithaus

College of Art, Sciences and Education

This thesis, written by Jessica C. Valdes, and entitled Much Ado About Contemporary Women: Gender Adapted in Contemporary Settings, having been approved in respect to style and intellectual content, is referred to you for judgement.

We have read this thesis and recommend that it be approved.

Andrew Strycharski

Heather E. Blatt

Vernon Guy Dickson

Date of Defense: July 2, 2020

The thesis of Jessica C. Valdes is approved.

Dean Michael R. Heithaus

College of Arts, Sciences and Education

Andrés G. Gil

Vice President for Research and Economic Development and Dean of the University Graduate School

Florida International University, 2020 


\title{
ABSTRACT OF THE THESIS \\ MUCH ADO ABOUT CONTEMPORARY WOMEN: GENDER ADAPTED IN CONTEMPORARY SETTINGS
}

\author{
by \\ Jessica C. Valdes \\ Florida International University, 2020 \\ Miami, Florida

\section{Professor Vernon Guy Dickson, Major Professor}

Shakespeare's Much Ado About Nothing has been reproduced multiple times in a contemporary context. This thesis focuses on two key productions, BBC's ShakespeaReTold televised adaptation and Joss Whedon's 2013 film and examines how these productions translate the gender themes in the play to a contemporary setting. To study translations of gender, this thesis is focused on the adaptations of Beatrice and Hero, two major female characters of the play. The comparison of these adaptations is accomplished through analyzing the pieces and reviewing existing work. While there are some important differences between the adaptations, the major problems Beatrice and Hero are limited by as women are problems that can be successfully transferred to the contemporary setting. Conclusively, these adaptations choose to demonstrate that women facing limitations in their own microcultures have the agency to accept these limitations or try to do something about them. 


\section{TABLE OF CONTENTS}

CHAPTER

PAGE

SECTION 1: INTRODUCTION TO THE THESIS ……………………………........ 1

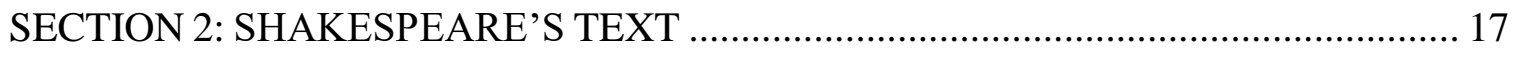

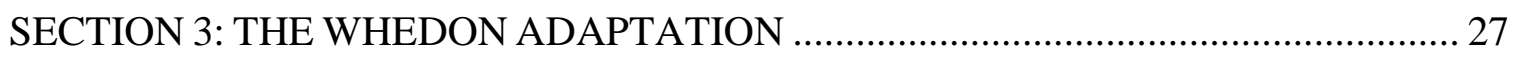

SECTION 4: THE BBC'S RETOLD ADAPTATION ……............................................. 38

SECTION 5: ADAPTATIONS IN COMPARISON …............................. 51

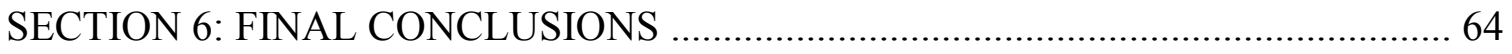

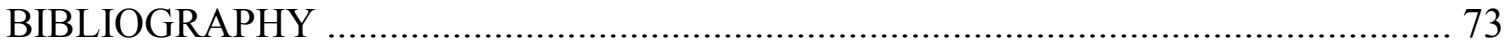




\section{SECTION 1: INTRODUCTION TO THE THESIS}

Stories, especially the well-known or the highly regarded, are frequently retold and reimagined. It might be throughout medias or throughout time. It might be for artistic expression or quick profit. It might be because some stories have an unknown quality that mystifies audiences repeatedly or because those stories influenced the storyteller before they began telling their stories. Regardless of how these re-creations come to be, they make some degree of changes to the original. These changes allow the story to become a new work. At first, the work might not seem like something new, but in revisiting the first work and adding new flourishes and combinations, a separate experience is made.

Through these processes, of telling and re-telling, stories can develop like a species adapting over time in many possible ways. While some may consider these recreations to be acts of appropriation, the process of recreation can also be an evolution. Even those trying to accurately depict the inspiring work must make decisions that stem from their own perspectives. Consequently, these stories are not simply reminders of where humankind has been, but they also connect themes to map out the moments in which a story finds itself. As these themes are adapted, new meanings and ideas can be explored through familiar lenses. My thesis will explore how two contemporary adaptations of Shakespeare's Much Ado About Nothing reinterpret thematic representations of female relationships to power in a patriarchal context and connect them to a contemporary setting.

There can be little doubt that the influence of Shakespeare and his work is immeasurable. These are stories that have lasted centuries and have spread all over the contemporary world in incalculable adaptations, performances, and script copies. 
Shakespeare himself retold older stories within his own work. When a Shakespearean play is recreated, the re-creation is to some extent connecting generations of storytelling to one another. Shakespearean plays have been learned enough that when an artist chooses to re-tell one of the plays, it is recognizable. The depiction of a Shakespearean work portrays a story that not only will be already known to some of the audience, but it will also draw the attention of those who seek out Shakespearean works and adaptations.

By using the term adaptation my thesis focuses on the process by which the Shakespearean narratives adapt and are transformed for contemporary audiences in a contemporary setting. There is the possible term of appropriation, but the connotation of that word implies a degree of violence and taking. In her essay, "Recognizing Shakespeare, Rethinking Fidelity" Christy Desmet suggests, "If we see appropriation as a dialogic transaction rather than theft at the expense of another, we are in a better position to look at appropriation in terms of artistic reception as well as production" (43). The idea of a transaction between the works is of import. In their essay, "Shakespeare and the Ethics of Appropriations," Alexa Huang and Elizabeth Rivlin explain the term appropriation also implies an understood subject-object relationship where the appropriation is the object acting upon the original as its subject (2). Huang and Rivlin continue to suggest appropriation does not necessarily need to be read as meaning a violent taking. Instead, it is possible to also see the original text as the subject and the adaptation as the object. For example, the original could affect how the adaptation is perceived or it can dictate limitations on the adaptation. Neither must be viewed in either role, necessarily. As Huang and Rivlin point out, 
We would be hard pressed to say that Shakespeare's work is incidental or inconsequential to his appropriators; to the contrary, an appropriator's reconstruction of Shakespeare always factors into the new work... they display self-awareness about their enmeshment in intertextual relationships and their interdependence with other texts. (5)

It would be limiting to view adaptations of Shakespeare only from the perspective of how they compare against the original. Such perspectives would dismiss the possibility of making new connections with the work. When looking for a subject and object the original and the adaptation itself need not be the only terms considered. There are also the producers and the audiences or the message and the interpretation. The term adaptation, instead of appropriation, implies flexibility. The connotation of the word adapt ties into ideas of evolution and new iterations. Adapting creates images of a person or a species changing because of the changes around them while appropriation calls to mind a violent theft. For purposes of my thesis, these two films are not Shakespeare's original. My thesis is more concerned with what these films, derived from and related to Shakespeare but still their own unique work, have to say about longstanding themes of gender in the contemporary context.

As a result, while the original text will be discussed, it will not be the center of my thesis. In his essay, "Shakespearean Rhizomatics" Douglas Lanier warns that often reviewing adaptations begins with the idea "that they are supplemental to or dependent upon the real Shakespeare" (23). They are often judged by their ability "to preserve that text's authority" (26). When Shakespeare's work itself comes from other narratives and the forms of the text read today might have had all sorts of differences when performed and in how it was published. To look for an original text of complete authority is a problematic and impossible pursuit. Such a pursuit connects to the idea of a narrative 
being adapted and adapting rather than necessarily seeking the one true interpretation of the original. Shakespeare himself was often inspired by other works that preceded him in addition to adapting his own work over time.

Instead of giving authority to the original text or to adaptation of the text, my thesis seeks to explore the creative choices and decisions made in the depictions of Hero and Beatrice. Lanier recommends a rhizomatic approach to Shakespearean texts and adaptations. To simplify, the idea bases itself on the work of Gilles Deleuze and Felix Guattari and concerns itself with the possible connections and intersections between various objects rather than the authority of one object over another. Approaching Shakespeare with these kind of perspective "stresses the power of those everdifferentiating particulars - specific adaptations, allusions, performances - to transform and restructure the aggregated Shakespearean field into something forever new" (31). Lanier additionally points out that approaching through such a perspective changes the responsibility of the study to look at the "creative potentials" rather than "stand as guardians of authenticity" (33). Rather than looking at whether or not the depictions of Hero and Beatrice are accurate, the focus can be on the ways the characters are transformed through adaptations and the ways in which the themes surrounding them in today's context connects and relates to what was previously in the text. The text does not need to be completely excluded from such an analysis. Desmet proposes that appropriations have power in helping audiences make different connections when faced with a reproduction. The tensions that arise between the differences and resemblances "connects texts across time and space" (55) and gives its audiences combinations of recognition as well as insight. These textual approaches require looking at an individual 
text and an individual adaptation, or several individual adaptations, and seeking out the ways in which they connect.

With certain adaptations since the turn of the century, Much Ado About Nothing has drawn a significant amount of attention. While Lanier reports that the 1990s saw a boost in Shakespeare being brought to contemporary a context, that the trend mostly died out; however, Much Ado About Nothing is one of the plays that breaks from said trend.

Of interest to my thesis are the adaptations of Much Ado About Nothing that bring Shakespeare into the contemporary setting and, in doing so, create a direct conversation between Shakespeare's themes and contemporary culture. My thesis will particularly consider how Joss Whedon's Much Ado About Nothing film adaptation and the BBC's ShakespeRe-told: Much Ado About Nothing television adaptation connects the themes of social/outsider status for female characters by the perceived gender binary from the original play to contemporary tensions. Lanier cautions against defaulting interpretations of adaptations through comparison to an idealized original play. Rather than focus exclusively on how these two adaptations compare, my thesis seeks out the conversation that takes place as the play is brought into a contemporary context for contemporary audiences. Both adaptations discussed make deliberate breaks with fidelity, breaks that arguably help bring them to their reimagined settings. Lanier states that "historically, infidelity to Shakespeare's text(s) has been just as important to Shakespeare's extraordinary vitality in world culture as have been principles of textual fidelity” (“Shakespearean Rhizomatics” 34). If Shakespeare's works have become widely enough well-known, the adaptation of his plays in other forms invite conversation about themes that human storytellers have concerned themselves with for centuries. That the story can 
be adapted and changed and altered allows it to intersect with a variety of cultures and societies. Huang and Rivlin point out that appropriations raise these sorts of questions because they are aware of being interconnected with other texts and productions. Appropriations "conjure different interpretive possibilities that already inhabit Shakespeare's texts." Huang and Rivlin continue to propose that "The ethical responsibility of the critic shifts from delimiting the boundaries of Shakespeare to tracing the ever-changing potential of 'Shakespeare"' (9). It is a disservice to Shakespeare's text to limit them only to attempts at authenticity. When Shakespeare's work begins to be put into new and creative combinations, such adaptations can speak to new audiences and further conversations and connections in how people perceive the related themes.

Much Ado About Nothing is a Shakespearean play following the interaction between two social groups. The story takes place of the home of Leonato, the patriarchal center of one social group, who runs his household of extended family and servants. In terms of plot, the most significant members of his family are his daughter Hero and his niece Beatrice. The second social circle is led by the prince Don Pedro who stays with Leonato on his return victoriously from war. He is accompanied by loyal men, notably Claudio and Benedick, in addition to other servants. Don Pedro also comes with the captive Don John, his bastard brother that fought against him during the war. The comedy spins a love story between Beatrice and Benedick while balancing itself on the interactions that occurs when these two social circles attempt to unite, through marriage, Don Pedro's loyal man Claudio with Leonato's daughter Hero.

The mutually beneficial alliance between these two powers is jeopardized by the story's conflict. Don John manipulates most of the other characters into doubting Hero's 
virtue. The resulting doubt causes Claudio and Don Pedro to denounce her on the day of the wedding and infuriates Leonato, first against his daughter and then against the other men. Beatrice laments not being able to protect and defend her cousin's reputation and wishes she were a man, which would give her the power to do so. The situation is solved when proof of Don John's trick surfaces in combination with Leonato spreading word that Hero had died of grief at the accusation. Leonato's trick replaces any lingering anger with sorrow and elevates Hero to an almost martyr-like status; she was so pure that even the accusation of infidelity and fornication was enough to kill her. Claudio is then asked to marry a cousin who turns out, after the marriage is settled, to be a veiled Hero. At times, the play skirts near a tragedy, but ends happily, with Hero and Claudio joined in matrimony, with Beatrice and Benedick in line to follow, and the uniting of two groups into a single well-connected one.

The conflict between the characters arises from two sorts of spaces. The first is the inclusion of Don John who, as a royal bastard, has no real place and yet must be on the edges of his brother's company. His royalty means certain privileges and positioning, and yet it also means he can never be fully accepted into the social sphere. By birth, he is an outsider and a villain. For his part, Don John appears to accept his given role, and while his mere existence is a disruption to social norms, he is more than willing to act out and further that disruption. There is little motive for him in the play other than disrupting the union that would bring his brother more power because that disruption was in his power to do so.

The other source of disruption comes from Hero and Beatrice. From birth, they are also outsiders of the social sphere they belong to but cannot escape. While Don John 
is kept from power because of his bastard birth, their exclusion is because they are women, whom Leonato must fully control to maintain status. Whereas Don John is actively trying to disrupt the union being developed, Hero and Beatrice are ideals of what women of the period should be like. And yet, it does not matter that they are privately, and in actuality, above social reproach. Just a little bit of circumstantial doubt is enough to destroy Hero's reputation and bring Beatrice's helplessness to light. Their mere existence opens Leonato's home to the possibility of disruption and there is little they can do on their own to effect that.

These feminine politics are worth investigating. They present major themes that needs be confronted by any re-imagining. The presence of such themes is not meant to argue that Shakespeare is or is not feminist, but rather to consider what reimagining Shakespeare in a contemporary setting might reveal. In her essay, "Fathering Herself: A Source of Study of Shakespeare's Feminism," McEachern points out that it is debatable if there can be found traces of historical feminism in Shakespeare's work, but that his work is still worth examining with feminist lenses. In my thesis, the focus is on the transformation of the gender themes within the tale when brought to a contemporary audience. Even the hypothetical ignoring of these themes would be a statement because it would connect in conversation with the original. Just because ideology has changed over time does not mean that the effects of said ideology have changed. Shakespeare frequently puts male relationships and romantic relationships against each other thematically, and part of the resulting tension stems from the ideology of the time where men were understood as "whole" as compared with women (Erickson 3). That view is no longer one that is commonly held and yet, it is still entirely understandable that a man's 
romantic relationship could come in conflict with his other male relationships. A major challenge in adapting a play like Much Ado About Nothing, particularly adapting it to a contemporary setting, is in dealing with the sexism and gender issues inherent within the text itself. How are these themes adapted into a contemporary audience? And specifically the intended audience of each production? In Shakespeare and the Problem of Adaptation, Margaret Jane Kidnie explains that one of the challenges in adapting the play is dealing with the ending where Hero forgives Claudio for the harm he brought her. Why should she in a contemporary context? As Margaret Jane Kidnie points out in Shakespeare and the Problem of Adaptation in reference to BBC's ReTold version of the play, 'Shakespeare's works are never just 'told' - and that at least in this particular instance, for this particular audience, he did not get it right" (111). Thematically, these issues of the feminine having complex relationships to power remain relevant and adaptations of the play have a lot of room to reincorporate such patterns.

The investigation of contemporary setting in adaptations can provide useful insight on possible perspectives. The use of a contemporary setting is far more than a stylistic or aesthetic choice; particularly in regards of the thematic uses of gender and agency, the contemporary setting is of key significance in the performances. To be commercially successful, a contemporary adaptation of Shakespeare must be sufficiently believable and relatable so that the audience will be able to enjoy it. It would be important to focus on adaptations that were both well received and reached audiences effectively as those pieces which achieved both these qualities show a degree of resonation within society. Moreover, it is those spaces of Shakespeare recreated in a contemporary context that, resonating with the contemporary audience, will be most 
useful in measuring gender identity politics. What is clear is that there has been quite a bit of interest in producing contemporary versions of Much Ado. Could something about the change in setting resonate with contemporary audiences? In the New York Times review for Whedon's film, reviewer A. O. Scott states, "Here I should confess a bias. I prefer my Shakespeare in modern clothing and with American accents, and so I like Mr. Whedon's take on Much Ado About Nothing better than Kenneth Branagh's star-studded, fancy-dress 1993 version." As a generally respected critic of public culture, Scott's admission here might well reflect the views of many. The selection of a contemporary setting is intriguing to viewers.

Bringing the themes into a contemporary world creates additional questions regarding how the understanding of gender and power has developed over time. McEachern mentions that recent feminists have been trying to look past a binary view between structures of feminine power of the past and traditional patriarchy and, in regards to said search, McEachern states that "As a consequence, it would appear that the woman's part, and the men's, are hardly essential and stable categories of identity but contestable and changeable social constructs" (271). The understanding of the straight male and female binary has been deconstructed and a plethora of identities and interests are in the process of becoming accepted within the social norm of the human experience, though it is not necessarily true of all contemporary people and places. Those who do not conform to the male/female binary are still facing physical and psychological danger. McEachern continues to point out that,

At the heart of patriarchy is the conflict between the emotional integrity of the family and the demands of a political order that requires the severing of filial bonds in order to perpetuate itself. Patriarchy is, in fact, comprised 
of two principal systems of affective loyalties: the family, over which the father rules, and a socio/political system founded on male alliance, in which the father is invested. (273)

Patriarchal values create a great deal of the conflict within Shakespeare's play. There is the male alliance each male character beyond a certain rank must contend with, but also the loyalty and intimacy within the household the play is centered in. McEachern points out the conflict between Leonato's affection for his daughter and the desire to marry her off in exchange for Claudio's connections and to be a part of the world around him. Her potential betrayal not only ruins his social opportunity, but it is also a personal betrayal to his leadership. His first violent response to her, once he becomes convinced of her innocence, flips to a violence against Claudio. For Beatrice and Hero, they will need to navigate a world of men in conflict with itself. However, how do the relationships between men, women and power change when brought from Shakespeare into the 2000s?

These two adaptations are of interest as streamable, accessible and well-reviewed content within the desired time frame after the year 2000. Both adaptations explored in my thesis brought the play into a contemporary context after the turn of the century while having sufficient exposure to possibly influence future work. Additionally, there are several theatrical performances with big name actors that bring Much Ado into a contemporary context featuring high profile actors, such as the 2011 version starring Katherine Tate and David Tennant or the 2019 performance featuring Danielle Brooks as Beatrice. However, performances like these are more limited in the scope of their audience. While certainly there are those who will search the web for a way to watch them, it is not quite the same as having access to a medium leant to the streaming consumption. There are additional, though less successful in terms of rating, reception 
and spread, film adaptations of Much Ado found after the turn of the millennium as well, in 2010 and 2013, in which the play takes place in a modern setting. There has also been an extensive YouTube series Nothing Much to Do web adaptation created by The Candle Wasters that trended for a short time which, though limited in its final audience, shows clear signs of being inspired by Whedon's work and presents a great deal of interesting gender choices including the inclusion of queer characters. Unfortunately, at over 100 episodes, the YouTube series is not the most approachable adaptation and views have remained mostly stagnant since its completion.

Joss Whedon's 2013 production began as a retreat to his home from other responsibilities. Accompanied by many of the film and television actors he'd worked with and befriended in the past, they produced the film in two weeks on a relatively low budget. Despite the situation, critics and general audiences both considered the film to be an overwhelming success. The film pulls Shakespeare into a contemporary setting offering a close up of the lives of a wealthy group of friends and associates, though it keeps the original language with an apparently affluent crowd using the Shakespearean language as if it was completely normal. The film utilizes most of the original script and, while there are some edits for length, the most significant changes are all done without additional spoken words.

In Joss Whedon's production of Much Ado About Nothing, the contemporary setting combined with the keeping of the original text create a disquiet concerning gender: the plausibility in which the events of Shakespeare's play are brought to such a setting indicate that perhaps the misogyny and chauvinism contemporary audiences associate with Shakespeare's time are not as far from our contemporary reality as they 
would like to believe. While Whedon's film certainly features components that feel like stage performance, it ultimately creates a certain sense of cinematic realism. The decisions to film in black and white, display the characters as an affluent social circle and the use of formal costumes add to the traditionalist tone of the film (Mahony 119). While certain cinematic choices might break audience immersion with implausibility, there is nothing implausible about the way the misogyny is presented. Furthermore, it is important to note that audiences do in fact find the plot, as presented by the script, still works. As one blogger, Sara Harvey, said in a post titled "Shakespeare, Feminism, and Joss Whedon":

But the very best part of Whedon's 21st century adaptation of Much Ado was how little he had to change. Which was not much. In fact watching both Whedon's version and Branaugh's version, the lines haven't changed, but the setting and the context has. And this is why I think Much Ado About Nothing has such a universal appeal, it is so easily adapted and so easily understood in our modern world.

Contemporary audiences found the adaptations realistic enough to create a sense of immersion while viewing. That is not to say that there is no suspension of disbelief, but that the story could still be understood. Whedon's film accomplishes the immersion while staying closer the script and general plot than the BBC's ReTold version.

The BBC's ShakespeaRe-Told: Much Ado About Nothing, directed by Brian Percival, is a television film within a well-received series that put Shakespearean plays in contemporary contexts. The ShakespeaRe-Told adaptation places the characters of the play as coworkers at the same news station, run primarily by Leonard, Leonato's reinterpretation. While the Whedon adaptation sticks to the script, the ShakespeaRe-Told adaptation diverges from the script, not only adapting the script to fit the setting, but also 
making a number of changes to the plot particularly when it comes to the ending. A few of the many changes include focusing on Hero's loyalty to the men in her life as opposed to her chastity, uniting the two social circles as on under 'Leo' in a workplace setting, putting Hero's life in literal danger, having Hero cut ties with Claudio and distancing herself from her father and ending only in a wedding between Beatrice and Benedick.

For the sake of clarity, it is important to note that in looking at revelations of gender, my thesis contends with the assigning of roles to male and female bodies who accept their places in set roles. The play and its re-interpretations offer very little in the way of what is queer and, whether or not the performances are understood as masculine and feminine and their respective bodies are or are not completely relative, these are roles that continue to be assigned and represented. At no point does my thesis seek to push a designation on anybody, but rather it seeks to study the patterns or the presentations and performances of the body of words bound together by the play at hand. In Gender Trouble, Judith Butler shows how problematic feminist attempts are to define terms like woman and feminine. My thesis does not provide a solution to the dilemma, but rather the uses of these terms are intended only as approximation. To an extent, my thesis is comparing a previous construction of 'feminine' to contemporary representations of the same construction. One problem with the signifier/signified relationship of the adapted words and concepts is that it is in an unstable, moving and changing state. In both productions, depictions of Hero and Beatrice seem to accept their roles as 'women' even though the four characterizations are each unique from each other.

That the role cannot be defined or fixed does not change that being assigned (and accepting) such a signifier comes with consequences. Butler explains in her preface that 
conflict occurs when "that masculine subject of desire" encounters "the unanticipated agency, of a female 'object'” (vii). Neither Beatrice nor Hero exist in a vacuum but instead should be examined in the context of their surrounding microculture and the constructed structures that surround them and that they choose to or choose not to participate in. In being born with a vagina rather than with a phallus, Hero and Beatrice are marked by their female bodies that makes them other to the male characters around them and outsiders by birth. Butler explains that "In order to 'be' the Phallus, the reflector and guarantor of an apparent masculine subject position, women must become, must 'be'... precisely what men are not and, in their very lack, establish the essential function of men" (45). And yet, there are bound to be problems and anxieties when trapping a human being with agency into the position of an object and when said trapping is meant to define the success of the subject. Because, as Butler commends Jaqueline Rose for pointing out, "every identification, precisely because it has a phantasm as its ideal, is bound to fail" (55). The socially constructed ideals for masculinity and femininity both separately and in relation to each other is neither viable nor realistic. The result when trying to stay with those ideals must then be flawed and problematic.

My thesis contains four major sections in addition to the introduction and conclusion. The first section will explore how Hero and Beatrice are presented in the original text. The text comes first not because it is the priority or to focus on authenticity, but to best establish a basis to see where the creative choices of the adaptations began. The second section will focus on how Hero and Beatrice are presented in Whedon's film. What happens when most of the script is brought into a contemporary setting? As Beatrice and Hero are developed both within the language of Shakespeare's work and the 
contemporary setting, choices needed to be made to merge the two together. The third section focuses on the interpretations of these characters in the ShakespeaRe-told adaptation of the play. As the ShakespeaRe-Told adaptation piece moves away from the script, all sorts of choices needed to be made in how Hero and Beatrice would be adapted. In moving away from the script, the ShakespeaRe-Told adaptation even goes as far as to make deliberate changes to the ending. These changes all alter what audiences can see in Hero and Beatrice, and yet, the piece keeps the roles recognizable. Lastly, there will be a fourth section seeking to compare these versions of Hero and Beatrice. While their presentation in the script is still important, the primary focus will be on the presentations found in both adaptations. 


\section{SECTION 2: SHAKESPEARE'S TEXT}

The purpose of my thesis is to explore how of Joss Whedon's adaptation and the BBC's Re-Told adaptation of Much Ado About Nothing explore gender themes as they are interpreted into a contemporary context. Both adaptations are informed by the text they are adapting. To best discuss the creative choices of the adaptations, the original play's use of gender themes should be looked at first. In the script and in both adaptations, Beatrice and Hero are the two most prominent female characters and the plotlines follow the story of their romantic relationships. Understanding these two key characters and how they were originally presented is key to understanding the way the adaptations choose to handle the feminine relationships to power.

From the very first scene, Beatrice is a character that stands out. Although Hero and Claudio follow a more traditional romantic trajectory, Beatrice is widely considered the leading female role of the play as her banter and eventual romance with Benedick can easily overshadow Hero and Claudio's story. She actively critiques “the male world of soldiering and hell-raising" (Hays 80) and is the most vocal female character in the play. Despite her boldness, however, Beatrice sees herself, and is throughout the play presented, as someone completely acceptable within her social context and actively avoids stepping outside the acceptable (Bamber 38, 40). From the very first scene, Beatrice's wit is established. Beyond that, and potentially of equal importance, her wit is shown to be acceptable to the men around her. It is received with playful retorts on the

part of Benedict and amusement from the other male characters. At different points, both Hero and Leonato need to explain her to the messenger, who finds her rather odd, but 
even in the introduction she is presented as the sort of high woman only a man with exquisite tastes can properly appreciate.

Hero is introduced in the same scene as her cousin, but the play immediately establishes that she is an entirely different sort of woman. For one thing, while she is physically present, Hero speaks only once among the $300+$ lines in the first scene, even though she is physically present half the time. She possesses enough presence that she is remarked about; the men discuss her considerably in the first scene, though when she is present during such talk, they discuss her like an object and like she is not entirely there. When she is gone, she continues to be compared to a "jewel" in line 177. Her name, however, connects her to the mythological Hero who was devoted to Aphrodite and makes love with Leander in passion outside of marriage (Suzuki 130). The mythological Hero drowns herself when she loses Leander to meet him in the afterlife. The tragic connection between the two Heroes makes it particularly troubling as the plot continues as the play could have veered into tragedy instead of comedy. As it stands, she is physically weakened by the accusations to the point where she collapses, she faces threats of death from her father and she has to undergo a fake death.

As the two female leads in a play that closely follows two couples, Beatrice and Hero become key to unpacking themes regarding women, including their relationship with power and position. While there are other women in the script, they rarely speak and, as servants, are not part of the social circle my thesis will be focusing on; their status limits their voice and their access to power. Beatrice and Hero, on the other hand, must navigate being part of the social circle as women within Leonato's household in the play's double romance; they have some voice, but the power falls mostly to Leonato. He 
is Hero's father and directs her very closely. When his household finds out that Claudio is interested in her, he directs her in exactly how she is supposed to respond, something that the entire household seems to understand. While Beatrice is not technically his daughter, the guidance is definitely still there, and she clearly shows respect for him as the head of the household.

Despite the differences between Hero and Beatrice, they are both clearly meant to be established as desirable and noble women. Beatrice is witty and active, but not actually threatening to masculine authority, while Hero exhibits the more submissive, docile woman; regardless of those natures, the men in the play clearly indicate that both women are desirable (Park 102). They are of desirable rank and upbringing.

There is no question of how desirable Beatrice is. Before deciding to get the group to get Beatrice and Benedick to fall in love, the Prince asks her if she will marry him. She gently turns the prince down with a well-placed joke and it not entirely clear whether he was serious or not. However, it is clear he thinks her worthy of Benedick, his man in arms. In Act 2, Scene 3, Benedick goes into describing the perfect woman and the only sort of woman he would ever be willing to marry. The idealization implied indicates a fantasy woman that is of high birth, wise, virtuous, beautiful, well-mannered, has a noble nature, is good with conversation and has some musical talent. While it is not known if Beatrice has musical talent, she does seem to meet his other requirements.

In contrast to her cousin, Hero exemplifies those traits often associated with a different sort of desirable woman. She is clearly of a much softer disposition. The Prince, upon first seeing her in the play, honors her for resembling her father, which is a mark of her legitimacy. Later in the same scene, Claudio expresses interest in both her modesty 
and her sweetness. She is obedient to both her father and goes along with the Prince's schemes. Although very different from Beatrice in presentation, there is much to Hero that makes her desirable to men.

These presentations all show to be important because that desirability, which is founded in their trustworthiness, comprises Beatrice and Hero's primary source of power within the social sphere. Trustworthiness is what makes the desirability possible. During the period, women were categorized according to a binary of whether or not they could be trusted. Either a woman would be entirely trustworthy or not capable of being trusted at all (Erickson 7). Such strict and limiting identities of course define them by their relationships with men. Both Beatrice and Hero are completely trustworthy women, and yet, the doubts that occur anyway despite their blamelessness causes most of the conflict within the play.

Another source of power Beatrice and Hero have is their relationship to each other. Together, Beatrice and Hero present what is potentially the strongest relationship within the play; there is even speculation that the men might think there is some sexuality between Beatrice and Hero (Jankowski 311). Ultimately, it is the strength of their relationship that keeps the story from becoming a tragedy rather than a comedy. When Hero is slandered, Beatrice's reaction is decisive being "guided by the truth, whereas the men make choices in the absence of certainty" (Bamber 121). Her reaction supports Hero with strength and keeps Hero going. However, Beatrice wants everyone accusing Hero to suffer and particularly wants Claudio dead. Alone, Beatrice might have stayed focused on anger and revenge. Hero's gentle and obedient nature is what allows for the play to end with a wedding rather than bloodshed. She chooses to go along with her father's wishes 
and the friar's scheme. Beatrice goes along with the scheme even posing as one of the veiled young women. Both women must participate in order to prevent the play from ending tragically.

Beyond their individual qualities and their relationship with each other, the gender mobility each woman experiences is firmly founded in the society that they keep. The play "brings the traditionally male sphere of war, honors, and triumph into contact with the private and potentially expressive world of Messina, a world whose functioning is communal and cyclical and whose heirs are women" (Hays 79). Leonato has no young men to continue his line and so there is a degree of anxiety that results from his whole household relying on Hero's virtue. The men “...must choose between a woman and the world of men by whom she is condemned. Claudio chooses the old world of male solidarity" (Bamber 120). Both Benedick and Claudio struggle with the idea of marriage although they go about it differently. Both are successful in the male sphere but reluctant to putting their reputation on the reliance of a woman. In "The Order of the Garter, the cult of Elizabeth, and class-gender tension in The Merry Wives of Windsor" Erickson explains that "Patriarchal conventions that promote male power are significant because they cannot, in Shakespeare's work, be taken for granted as an automatic, settled norm. Instead, patriarchal concern has to be negotiated each time, and the outcome is variable and uncertain." Shakespeare's Much Ado About Nothing is a play all about these negotiations. For all that Hero and Beatrice must become followers of the male head of household, be it father or husband, the men who hold them are reliant on their virtue for their own reputations. Thus the power that is uniquely their own creates an anxiety among the men who for all other purposes own them. 
Despite being part of the group, Beatrice and Hero are women in a male-centered world. As the men are dealing with establishing, strengthening, and disrupting households, Beatrice and Hero are commodities making these negotiations possible. Throughout the play, Hero is referred to or spoken of as an object. Not only is she compared to a "jewel" at the beginning of the play, but she's also referred to as "a bird's nest" (2.1.220), Claudio's "new coat" (3.2.6), a "precious gift" (4.1.28) and "this rotten orange" (4.1.32). It is never completely confirmed that Hero would like to marry Claudio. In Act 1, Scene 1, Claudio states he is in love with her and wants to marry her. In the very next scene, Leonato's brother informs him of Claudio's interest and Leonato, liking the match begins to prepare his daughter as to how to answer. Then, in the third scene, Leonato is discussing marriage with Beatrice and Hero. He reminds Beatrice that in marriage she should "be ruled by your father" (2.1.51) and, a few lines later, he reminds Hero of a conversation they had about what her answer to Don Pedro's courting should be (2.1.65-67). And, while Beatrice seems to maneuver better than her cousin, she has to deal with the male-centeredness of her world too. When Benedick is tricked into believing that Beatrice is in love with him in Act 2, Scene 3, the men compliment him a great deal and praise him for being "a proper man" (187), "very wise" (189), and "valiant" (192). The suggestion that it is one of his only flaws that he would never take Beatrice's love for him seriously. In contrast, while Benedick is persuaded with flattery, Beatrice is tricked with criticism. In Act 3, Scene 1, Hero deliberately discusses Benedick's supposed love for Beatrice as something Beatrice should not be told. Among other things, Beatrice is criticized for being overly proud (52), full of "disdain and scorn" (53) and not willing to hear anyone's advice (77). Hero and Beatrice are limited and put 
on the outside of the system because they are ultimately ruled by them. And yet the reason they are so threatening is because they are not controllable static objects. Their bodies are their own and no amount of social control can guarantee that they will stay in their place. Benedick only goes after Beatrice when he has the knowledge of her interest, making her a safe course. He sufficiently believes in her virtue and nobility that once he knows he has her affection; he does not stop and doubt that there will be a problem. Hero, on the other hand, receives such intense rhetoric from both her father and Claudio precisely because of how much damage her virtue or lack thereof can create. Claudio calls her worse than "pampered animals that rage in savage sensuality" (4.1.60-61) and her father both wishes her dead (4.1.131) in addition to talking about killing her (4.1.135). It is not her actual actions that cause problems, but her potential as an independent body to cause problems that give Don John's schemes their power.

The central conflict caused by Don John's schemes show both the extent and the limitations of the feminine power Beatrice and Hero have access to. First off, Beatrice and Hero start the play in a position of as much strength as they could get within their respective positions. Their honorable reputations and positive relationships with each other give them, within reason, most of the potential leverage they can have as unmarried young women. Secondly, the slander that nearly destroys Hero completely was not within either young woman's power to avoid. Despite a lifetime of honorable behavior, it takes the scheme of one night to strip that away from Hero. While both women can be viewed as potentially threatening, these threats tend to result more from male insecurity and less from the women themselves. Beatrice could have been just as vulnerable, but the trick focused on Hero since Hero's transfer from Leonato's household to Claudio's was the 
focus of the negotiations. However, because only one of them is accused, the two women have very different struggles with power.

Beatrice's struggle with power stems primarily from her inability to protect Hero. While Hero is arguably the victim of the play's conflict, Beatrice is the person who at once witnesses and recognizes the events as tragic and unjust. She is someone who supports Hero and does not doubt her, and as stated before, that is not without merit as it helps Hero keep going. Recognizing that society has not given her the power to act in defense of poor Hero, Beatrice wishes she were a man so that she could defend Hero's honor and set things right. She even goes as far as pulling away from Benedick's romantic interest. Despite seeming to be genuinely interested in Benedick, as shown later in a poem she wrote, she pulls away from the romantic relationship and leverages her desirability to get Benedick to act on her behalf, since he can act while she cannot. Beatrice realizes he is the only acceptable way she has to deal with the situation and takes the actions that are afforded to her.

As the person being directly slandered, Hero is confronted more clearly with her own limitations. Despite her loyalty, that the men bought in to her infidelity so easily demonstrates how "...Hero is for them little more than a pawn on the masculine chessboard" and her virginity becomes a matter of male pride (Hays 87). Her situation reflects a common pattern for protagonists in Shakespeare's comedies: they must endure suffering or failure, but by surrendering and accepting it, they earn a happy ending (Hays 90-91). It is through submission that she gets to use her form of power within the play. Beatrice and the Priest that was supposed to marry her, urge her to fake her own death and she is mourned before reappearing at a second wedding with a repentant Claudio. 
When she is revealed, it serves as a rebirth, a celebrated part of traditional feminine experience of power (Hayes 91). Kirsch points out that Hero has even been compared to a Messianic figure (54). Although innocent, she goes through a figurative death and rebirth cycle to redeem the relationship and help Claudio work through his mistake. A problem with the situation, however, is that Messianic status implies a willing sacrifice. Hero does not have a real choice. Her father has decided she must do, and she was not in any way related to Claudio's misconception or humiliation of her other than as a victim. Redeeming Claudio is the only way to protect herself. There has long been a pedestal where the virtuous woman helps her man, but it traps the woman in a limited binary of acceptability. Hero meets these standards because she knows what is at stake if she does not; her value comes from her status and it turns her body into an object to be bought and sold or seen as broken.

In the text, Beatrice and Hero are dramatically linked. Though they have very different personalities, they are both desirable women of similar rank. Because they are women, they are on the outskirts of the circle whereas the men lead and establish the household and do the negotiating. Their desirability does give them a degree of agency, but it can be easily torn away. When, potentially quite easily, they are confronted by the limitations of their agency, they must rely on their relationships, desirability and honor to make it through. As Arthur Kirsch points out in Shakespeare and the Experience of Love, the anxieties about male to female relationship fuel the jokes Beatrice experience as well as the actual experience Hero must face (68). Beatrice and Benedick exchange jokes revolving around sex, gender, and disloyalty while Hero must face accusations of infidelity from Claudio who is not consistent in how he approaches her. Kirsch also 
points out that, when Claudio lashes out against Hero the way that he does, it reveals how self-centered his idea of love is (57). He can humiliate her the way he does because she is an object that can reflect his fears and anxieties concerning fidelity. Hero must redeem him from his attitude to save herself, to protect her father's reputation and to end the conflict. Benedick also has an awareness of these anxieties and does not want to have the vulnerability of starting a household. Beatrice's desirability, her perceived safety that comes from the meddling of the other characters, and finally, her continuously honorable reputation pave the way for him to see her in a romantic light. Beatrice and Hero do not have access to the levels of power that their male counterpoints can have, however, it is the way they use the limited power that they do have that peacefully ends the conflict. At the same time, there were limits to their power from the environment around and the ending of the text never explicitly indicates that Hero is happy with the outcome. In transitioning to the adaptations, my thesis would like to consider what kind of power do these two women possess, what limitations their power has and how their power is adapted to the contemporary setting. 


\section{SECTION 3: THE WHEDON ADAPTATION}

Whedon's adaptation of Much Ado About Nothing is careful in how it brings the Shakespearean play into a contemporary context. While it is identifiable as a contemporary context given the technology, decorations, and other details, the audience can that more advanced technologies are barely used. There are cars, pools, and cooking utensils, but little to no use of cell phones, tablets or computers. Additionally, the film is shot in black and white, but the filming style itself and how scenes are framed is otherwise contemporary. In his article “'Good lord, for alliance': Joss Whedon's Much Ado About Nothing" Lanier points out that Whedon's production mostly utilizes close ups and three-camera set up in order to focus in on each actor's performance (121). By focusing the cameras on the characters, the film accomplishes a sort of traditional tone that helps merge the language of the script to the contemporary setting. And while much of the script is left intact, bringing the script to the contemporary setting does change enough to be an adaptation rather than an interpretation.

The film seems to focus more on the group dynamics than any specific character. In most scenes where any given character is talking, the camera is quickly panning to and from that character to include every other character present in the scene, even those that do not speak at all. The contemporary group presented is not representative of all of culture, but that does not make their representation less important. The microculture that appears on screen is one of formality and affluence. The elegance and occasional extravagance of the location, the props, the clothing and the general atmosphere of the party are readily apparent. The group displays clear expectations for traditional, classical behavior. These are also the sort of people whose lives and decisions directly and 
indirectly affect the lives of lower classes either because of their political decisions or their cultural and financial influence. It isn't the luxury of celebrity lifestyle, but rather the prosperous lifestyle of political leaders. The status being presented potentially gives any problematic behaviors extra weight.

Our first introduction to Beatrice in the film is as a woman being left behind by a man. She pretends to be asleep as Benedick contemplates their relationship and then leaves her behind, thus having her passively wait to see what action he will take. He watches her back for a moment, thinking she is asleep though she is not, before deciding to move on. On one hand, the wordless additional scene takes away the once prevalent expectation that all women must remain virgins until marriage, an idea that is no longer part of mainstream society. While there is still a perceived value placed on female virginity, there is a contemporary understanding that many adults, both male and female, have been sexually active. At the same time, Benedick leaving Beatrice does reduce her perceived power in their dynamics, especially when the film begins with a silent scene where Benedick leaves her after they have had sex. While the text does seem to imply that they once had some sort of relationship, the film chooses to clarify that they were close enough to have sex. Especially in a group that has presented itself as so classical and traditional, in Beatrice choosing to have sex with Benedick she makes herself vulnerable to him. And, as a response, he walks away from her. The scene is understood to occur a significant amount of time before the events of the play and transitions to the beginning of the script. As the Act 1, Scene 1 dialogue begins, Hero and Beatrice are helping the servants prepare a meal in the kitchen, while Leonato and his brother keep apart from the traditionally feminine type of work. Her clever words are treated with a 
sort of amusement from the male characters while Hero remains present but silent in her introductory scene. The female space of the film is quickly set up to be a place of service.

Hero's introduction, in part limited by the script, is still a quiet one, but she is shown to be actively interested in Claudio. While she is being admired by the male characters, she comes closer to center camera, but is otherwise frequently found on the edge of the shot. At the same time, there is a significant difference between knowing she is present in a script and seeing the physical presence of a body on screen. The actress's coy smiles and emotive responses increase the perceived activity of the role, though the increase is limited by the script. There is implication in the way the other characters say the name "Claudio" and her reactions to that name that make it clear she knows him and is very interested in him. She smiles whenever his name is mentioned, and her smile is returned by Leonato and Beatrice at seeing her so happy. A few lines at the end of their family discussion are cut where Beatrice would have spoken on Hero's behalf when Hero is asked a question by her father. While several cuts are made to simplify banter, the edit helps the adapted Hero to appear like a quiet person rather than a voiceless one. As the scene moves forward and the Prince arrives with his party, there are still several instances where Hero is objectified and spoken about like she is not there. However, Leonato's brother is completely cut from the film and one or two of his lines is given to Hero. The cut is especially significant because it cuts Act 1 , Scene 2 from the film and it is the only scene completely removed from the film. The edit is additionally important because, in the play, Act 1, Scene 2 is where Leonato decides Hero should be with Claudio and tells his brother that he will instruct Hero in how he expects her to respond to being wooed. Between her reactions to Claudio's name in combination with the edit, Hero gets to show 
more agency when it comes to wanting to be with Claudio, even if said agency is presented nonverbally.

While the film focuses on the entire group, the group is still very much in a man's world. As the two sides of the groups meet, the lenses focus on the men, centering them into the scene in their suits while the women such as servants, Conrad and Hero circle quietly outside the main group. The blocking changes only when Beatrice, also to the side, draws Benedick to her while, of course, attending to the very domestic task that is tending to the garden. And, as soon as the other men come to speak to Benedick, she is sidelined in the scene.

Visually, the film visually presents the women as separate from the men. The men are all in suits while Beatrice and Hero are constantly in heels and dresses, doing household tasks as they move along. Even though there are clearly plenty of servants, they can be found helping in the kitchen or arranging decorations. Even as Beatrice meets the men coming to stay with Leonato, she briefly greets them before she returns to her task arranging flowers away from the group. As the introductory dialogue between her and Benedick continue, he must follow her into her work to interact with her. Their blocking also adds a shift in spaces between the men and the women as, once Benedick returns to his group, he is also returning to the male space created by the dominance of where the male bodies are.

The film uses side characters and extras to help create further differences between genders as well. Male servants are in white shirts and pants while female servants wear maid dresses in their scenes. In the party scene, there are two female acrobats in constant performance, but the party guests barely pay attention to them. Instead, their bodies 
become part of the background. Male guests continuously take the lead with female guests. Even as Beatrice delivers witty remarks against Benedick at the party, there is a unnamed male guest who keeps touching the skin exposed by her dress. Even though she keeps moving his hand away while she talks, he keeps touching her and eventually follows her into a dance. For all the witty comments she's made so far, that she keeps getting touched when she does not want to be starts pointing at the limitations of the power Beatrice has seemed to have had up until the party scene.

Much like the text, the adaptation presents a Beatrice who is at once able to maneuver well amongst the microculture she is in but who, at the same time, is limited by her gender. Despite being among the most vocal characters, she has her individual voice partially muted. By distributing camera attention fairly evenly among the characters, even those who do not necessarily speak much, the emphasis of the film is on the groups structure and interactions over Beatrice's individual voice, particularly when combined with the excellent acting provided by the entire cast. Dressed in the same formal, yet muted style of the rest of the group, she blends with them visually as well. Additionally, like Hero, Beatrice frequently helps with things the servants are doing such as arranging flowers or setting up the meal. She is at the party able to make remarks against Benedick but does not speak up when another male guest keeps touching her when she does not want to be. Even as the film creates a sort of visual parallel in how Benedick and Beatrice are tricked, Benedick is outside and active while he overhears the other men talking about how Beatrice loves him. Beatrice, on the other hand, must crawl on the floor of the kitchen to hear what the trick that Benedick is in love with her. While both moments are simplified when compared to the original script, the adaptation retains the general idea 
that the other men flatter Benedick while tricking him while Hero and Margaret trick Beatrice through criticizing her. Beatrice is presented as a vocal character who is consistently pushed to the side.

In considering Hero and Beatrice's agency, as well as the limitations of that agency, it is important to consider the limitations of sticking to Shakespeare's language. In choosing to stick to the original script, Beatrice and Hero are both limited by the standards that exist on paper. Hero will not be a vocal character and Beatrice will wish she were a man. On the other side, however, the film did have options in tone and blocking in how they presented these characters and the way others responded to them. In the final presentation, Hero is made a little more active, Beatrice can be perceived as being more subdued in the film and they both blend into the world around them. They are a part of the microculture and the gender problems presented within it.

As with their textual counterparts, Beatrice and Hero are not without any sort of power. The desirability of the characters is very clear, not only because of the lines but because of the way the men look at and react to them. Claudio is clearly smitten with Hero, Benedick has literally slept with Beatrice, male guests at the party show interest in both and the Prince pays a great deal of attention to both them when they are in front of him. They are adult women who seem confident in their own attractiveness, even if sometimes the way men react to them seem to be more indulgent than respectful.

Unfortunately, by fitting in with the group so well, Beatrice and Hero are giving up some of the potential power they could have as contemporary women. When things are going well, they are doted upon and comfortable. However, as conflict enters the story, both women feel trapped by their situation because of the roles they have accepted 
for themselves. These characters are grown women who are capable, at least hypothetically, of walking away. Yet, in determining that they want to stay in the masculine space of their microculture, Beatrice and Hero are subjecting themselves to the rules of that space.

While Shakespeare's lines might seem progressive for his time period, they are not words of strength today. In the original play, Beatrice's delivery of the "I wish I were a man" speech (beginning in line 329 in Act 4, Scene 1) is the pivotal part of her character. Up to Act 4, she has been consistently presented as strong, intelligent and bold; however, there are limitations to the sort of role she can play because of being female in the group she is in, something she is very much aware of. In Act 4, Scene 1, she is a frustrated woman, coming face to face with her own limitations, fully aware of the boundaries she feels she cannot cross. Her budding romantic relationship with Benedick blooms into an avenue through which she chooses to have agency as he agrees to act on her behalf.

When the moment of her speech is presented in Whedon's production, Beatrice comes across as weaker than the contemporary perceptions of the Beatrice in the text specifically because she exists in a contemporary context. Because of Shakespeare's time period, the moment seems like a powerful moment for Beatrice where she sees through the culture around her, but Whedon's Beatrice is a contemporary woman; seeing her in tears wishing that she were a man emphasizes her weakness and speaks to the constructed nature concerning her limitations; there remains an underlying uneasiness. Can she only act through Benedick? She is a contemporary woman; she should be able to stand up for her friend and be heard. The reality, however, is that no one in their circle is ready to 
listen to her. The defense she would be able to offer would be hollow and few of the things she has said have been seen to be taken seriously. Although the setting is different from that of the original play, the dynamics of the microculture Beatrice are very similar. However, that these lines can still be said does present a problem. If the microculture is representative of an affluent and politically powerful group, then that Beatrice feels the limitation of being a woman can be seen as having particular significant. The limitations she feels takes place within a group that is wealthy and influential. While the group does not represent all contemporary cultures, or possibly even most contemporary cultures, such a group has influence and a woman who wants to be a part of such a group may have to accept limitations.

The scene in which Hero is humiliated is haunting and laden with potential violence. Her movements and her father's movements are rough and jagged. That the rest of the film has up to the wedding has been light-hearted only serves to sharply contrast with the intensity of the moment. About half of her father's lines are cut, such as lines 134 and 135, where he suggests that if he thought she was going to lose her honor he would have killed her himself. These additional humiliations are not necessary to the heaviness of the scene and, in a contemporary context, lines like 134-135 would be difficult to forgive or overlook. Even in a contemporary setting, it is perfectly believable that she is severely punished for even appearing as if she might have been an unfaithful fiancé and, in the choices, she might have made, a failed daughter.

The emphasis in the adaptation is, however, not so much on her virginity, as on her faithfulness. When Don John first approaches the Prince and Claudio to ruin the wedding, much of the dialogue is cut or simplified. The cuts allow the emphasis of the 
conversation to focus on the line "the lady is disloyal" (3.2.97). And, in 4.1, while some of the language pertaining to virginity (like line 51) remains in the adaptation, quite a few lines that focus in on that being the main issue are cut from both Claudio and Leonato such as "Thou pure impiety and impious purity" (109) or "her foul tainted flesh" (line 151). The Friar's lines (165-179) where he seems to be able to tell just by her blush that Hero is still a virgin are also cut. What seems to primarily anger Claudio, the Prince and Leonato is that she has allegedly been deceitful and unfaithful.

Despite the contemporary context, it is not at all strange that her reputation is tied to the stability of her relationships with the men in her life rather than her actual actions. It is very understandable that there would be a father so caught up in his daughter's chastity as it becomes a condition of whether the daughter is loved. Her father, as in the play, feels betrayed and since he could not control her through persuasion in his kindness, there exists a moment where he might try to control her by physical means. He does not hurt her, but in his anger, he grabs her and shakes her. While a contemporary audience likely would not forgive him for physically abusing her, his frustration comes out in a physical way that seems understandable. These methods of leading the household still hold as believable today.

The adaptation continuously reminds us that Hero is quietly making active choices during the scene. First, it is clear she wanted to marry Claudio. Not only was the scene where Leonato decides what her answer must be cut, but as she prepares for the wedding, the film cuts lines from Hero's dialogue with Margaret. Within the scene in the original play on lines 24 and 25, Hero says regarding the dress for her wedding "God give me joy to where it, for my heart is exceedingly heavy." The adaptation cuts the line 
out and presents a Hero that is genuinely excited about the wedding. When Claudio is making his accusations, the adaptation has Hero try to step forward and defend herself though she is silenced. When her father is furious with her, Benedick holds him back from Hero, but Hero picks herself up and goes to her father before delivering her response to him regarding her innocence. When the Friar addresses the accusations and brings up his idea for faking her death, the lines he speaks to Leonato are cut; these cuts balance how often the Friar speaks to Leonato to how often he addresses Hero. When a funeral is held for her, she smiles sadly in Beatrice's arms watching from above and witnesses that Claudio mourns her and still loves her. It is an important moment because part of the reconciliation, for Hero, is being able to see Claudio's love manifested. And finally, when she reveals her identity after Claudio has sworn to marry her, she delivers them lovingly while gently cupping his cheek. In the dancing that takes place after the conflict is over, Lanier points out that "we see a full reconciliation between Hero and Claudio" (137). As with her introduction, she may be a quiet character, but she is portrayed as very clearly having things she wants and going after them.

Throughout the adaptation, Hero's father is still a significant authority over her. While he seems doting, his control is very much apparent. With the decisions made in the adaptation, it is no longer an arranged marriage, but rather a marriage Hero seems to want. She seems genuinely taken by Claudio and happy to please her father. And yet, she is an adult woman and her father controls much of her life. Despite the contemporary setting, within her microculture, she is still a component of his reputation. Despite only watching, however, she seems to be an active part of preparing her father's scheme, again implying that both Hero and her father want the marriage to Claudio to continue. There is 
a fine line here where those details that would be contemporarily abhorrent are cut, and the father is not presented in a dislikable manner, but he is still very much the controlling force in his household.

If the text's ending is happy because the chaos has died down and Leonato and Don Pedro were able to complete their negotiations, the film makes it a point that the ending is happy because all our central characters, excepting the villain and his associates, have what they want, including Beatrice and Hero. Despite all the microculture's flaws, the cast of characters seem to genuinely want the members of the group to be happy. As Lanier points out, Whedon is concerned with "the delights of intimate community and the trauma of its violation" (124). Their rigidity is at once the source of the conflicts of the story and yet it is not necessarily vilified. The women, as in the text, played a role in getting the story to the happy ending. Hero's blocking and poise makes her a more active conspirator in getting married to Claudio and she is also very active and excited in bringing Beatrice to her own marriage. Beatrice still does what she feels she can to be an emotional support to her cousin and push Benedick into acting. Their microculture is what both women have actively chosen, and they use what agency the microculture permits them to keep the group together and functional. 


\section{SECTION 4: THE BBC'S RETOLD ADAPTATION}

The ShakespeaRe-Told: Much Ado About Nothing is, by its own nomenclature, a re-telling of the play created for a televised medium. The production moves away from the script, though it throws in lines throughout the piece, and brings the characters to a contemporary British setting. Rather than having Don Pedro's men and Leonato's household, the characters are employees working for Leo at a local TV news studio. The change of setting of course changes a few of the relationships. Beatrice is no longer family, but rather the main anchorwoman. Hero is still Leo's daughter in addition to being employed at the studio. Peter (Don Pedro), Benedick, Claude and even Don (Don John) are all employees too. The ShakespeaRe-told adaptation focuses on them as one group rather than seeing them as two groups led by two men figuring out how to negotiate a merge. There is still, however, a clear hierarchy with certain positions, like those appearing on screen being of one rank, while crew and make up take the place of servant characters. It is still a story following people who are living life together, even if the social tie is the workplace rather than families and households. The more influential characters produce, direct and appear on camera. While they can all discuss things with each other, there is an unspoken social hierarchy.

The very first things we learn about Beatrice are that she is desirable, alone and has been hurt by her previous relationship with Benedick. The piece begins with the relationship between Beatrice and Benedick. She is preparing every detail for a romantic evening, while he meanwhile prepares to leave for a new job opportunity. The scene ends with her left alone at dinner, while he just leaves a quick call that he will not be making it after she has been waiting a while. The people she works with seem to be the only people 
in her life. While she seems strong on some levels, firmly establishing boundaries between her and her soon to be replaced cohost and correcting her boss for how he uses the term housewives when talking about women, the adaptation presents a Beatrice who plays reactionary roles to the men around her. Given that within the performance she is herself a performer, she wears skirts and dresses and heels, while also in bolder more gender-neutral colors for our first impression, though she does not wear them all the time. She maintains a professional image and she is often described as talented and skilled at her work. She is not known for being kind, but she seems to stand up for herself. In the second scene of the piece, a male co-anchor Benedick will replace is pushy, insists on having an affair with her even though she makes it clear she is not interested and he even tries to grab her bottom. Beatrice puts an immediate stop to it and has no intention of working with him again.

The introduction does present her with some authority in the workplace, however, it also codes her as feminine and yet authoritative with her clothing, position and the way the rest of the cast treat her. After her first co-anchor is fired, Leo tells her that he will be replaced by Benedick, her value is as a female co-anchor in a set. He dismisses her desire to attempt to handle it alone and makes it clear he wants a male and female team. The party, which is a costume party rather than a masquerade, serves to examine her wardrobe presentation further. Beatrice, dressed as Queen Elizabeth, appears both feminine and powerful. At the very same party, she deliberately antagonizes Benedick, pretending to think he is Claudio and then talking poorly about him. She goes with Peter (the quiet Don Pedro character) though is clearly not with him, so she enters the party from a position of power. These representations help establish her as a woman who is able to hold her own 
in a man's world. Although the adaptation features a more authoritative presentation of a contemporary Beatrice than the Whedon presentation, the feminine is still being very heavily coded.

The same is true in our introduction to Hero. Hero's introduction is clearly to be taken as softer and more girly. The girliness is seen in the way the actress carries herself, the soft way of speaking and the feminine color palette of soft pinks and yellows clothing used for the character. Amongst the cast members, she is seen as kind and approachable, unlike Beatrice. If Beatrice gives her coworkers wry looks and makes contempt immediately known, Hero offers big smiles and treats everyone sweetly. Soon after Hero introduction, Beatrice and Leo (Leonato) have a conversation about the way Don looks at his daughter. While he presents it as a fatherly concern, Beatrice comments that "all the men look at Hero like that; that's why you employed her," something that Leonard does not bother denying. He is deliberately using her physical appearance to his benefit. At the same time, she is a more vocal Hero than in the text and she is very well liked in the studio. Her appearance is not the only reason she is respected in the workplace and Claude compliments the way she manages to do her work. While her father mentions the way Don looks at her, Hero is managing the relationship on her own. It is clear Don is interested in her rather than in disrupting negotiations as in the script. Even though Don has made her uncomfortable, she continues to show him a great deal of kindness.

Despite that both Hero and Beatrice are employees along with everyone else, they are still navigating a world that is male dominated, though the reimagining is less forthright. Rather than making it overt, the differences are seen more clearly in relation to the men in the group. Unlike their male counterparts, both women must deal with 
unwanted advances. Both women are frequently prized for their appearance and much of the rest of the cast is very concerned about the romantic relationships Beatrice and Hero form. In addition to the differing treatment between them and their male co-workers, both Beatrice and Hero face individual challenges.

For Beatrice, the male-dominated atmosphere is something she encounters at work and keeps herself separated from. Or at least, she attempts to, though in truth, the film implies that she does not have anything but work going on in her life. Even though Leonard is in charge, she is comfortable enough to correct him to say women instead of housewives" When they are planning out new ideas for doing the news program, she wants to do a serious piece involving the mistreatment of the elderly by the government and rejects Benedick's misogynistic idea of covering the farmer's daughter that won a beauty pageant. Even the girl is not called a winner or a contestant but is primarily addressed as the farmer's daughter. Beatrice is very much surrounded by patriarchy in her workplace and, while she does not necessarily agree with it or embrace it, she does end up tolerating the underbelly though she confronts the symptoms that arise around her.

At first glance, there seems to be a sort of equality between Beatrice and Benedick, but as the film continues, that equality is complicated. Rather than having Benedick coming from the male sphere of battle and Beatrice from the female sphere of the household, they are both employees and co-anchors. That they share the same privilege, however, is problematic considering she has been faithful to the company and worked for them for years. Benedick, on the other hand, once worked for them, left to take a better opportunity, and then was hired back. He is rehired in part because they needed to replace the previous male co-anchor and in part because the chance he took did 
not work out. When he returns, however, he is immediately given the same priority as Beatrice, despite not having the same amount of years or loyalty. Additionally, despite her making it clear that she was not comfortable working with him, she must deal with him re-entering her world. She does what she can to resist him and try to outdo him and, when she seems to start winning the argument, her coworkers decide that what she needs is for the two of them to get back together.

Hero, on the other hand, must balance three men trying actively to control her life: Claude, Leo and Don. While Claude is clearly a partner she chose for herself, that is not enough to make the relationship healthy. Claude seems to care about her at first, but he is very controlling of the details of their relationship. As the film goes on, he is compared to Don, who is actively stalking Hero. Don, upset that Hero is not interested in him, plants doubt during the party scene that perhaps Hero has been with other men in the office. The scene utilizes the line from the play that suggests she is "everyone's Hero." In reaction to Don's remark, Claude marks his territory by announcing their engagement without warning her and when they were waiting to decide when to announce it. Claude neither talks to her about it beforehand or so much as warns her. He takes that choice away from her to keep other men away. Typically speaking, a wedding is seen as something that the bride primarily controls, though Claude is closely involved in the planning process. His involvement is not necessarily negative, and grooms sometimes do involve themselves in their weddings. However, his input is part of why Beatrice is chosen as Maid of Honor, a decision that is usually a personal choice for the bride. The decision seems to concern itself more with work hierarchy than personal relationship, something Claude or Leonard might care about more than Hero seems to, since in a (sometimes cut from the 
production) bachelorette party, she is shown to have female friends outside of work. Claude and Leo make decisions for Hero and she tends to go along with these choices. While she is more separated from her father than in the play or the Whedon adaptation, Leo is still playing a controlling role over her life. He is her boss at work and clearly takes a special interest in all she does. Right before the party, Hero goes to his home to get ready. He has left her bedroom just as it was when she was a little girl, which tells how he sees her, a little girl to be guided, and that he has not moved on from their previous roles. The absence of her mother may explain some of their closeness, but his words are telling. When Hero comments he does not need to leave her old room as is, Leo explains he likes it and ends with "Besides, you never know when you might need your room back." Despite Hero being an adult, her father still sees her as someone who fits in a little girl's room and he has not ruled out the idea that she could come back to live with him as his little girl. It is not necessarily a bad thing that he is a caring father and many parents would be willing to take their children back. What makes the interaction more intense, however, is the indication that, while he is willing to use her attractiveness, he does not see her as an adult woman at all. In fact, the implication is that she is welcome to come home and be his little girl up until she is married, while he is using her in the workplace for her adult body.

Don may not be as important a figure to her as her father or fiancé, but Hero does genuinely try to be his friend despite his romantic interest in her. Actually, Hero recognizes that he is overly fixated on her, but she remains patient and kind. As Margaret Jane Kidnie points out in Shakespeare and the Problem of Adaptation, 
...by reconceiving Don John's resentment... as a melancholic obsession with... Hero. The expression of a man's love for a woman through a jealous control of her sexuality, an aspect of the work that is already problematic for many twenty-first century readers and spectators, is made more troubling in this production by finding in 'Don' a near-criminal counterpart to Claude. (110)

He uses every bit of kindness she shows to try and control her, however, and frequently passes the boundaries into actively stalking her. Don does not respect her space whatsoever, feeling like he can go into her purse or her childhood bedroom and go through her things. She even tells him to stop following her home. However, he is manipulative and explains his pain, knowing that Hero is kind enough to stop and respond to it. The conflict that is caused is a punishment he creates for the perceived humiliation of her rejection. Between these three men actively involving themselves, Hero has much to navigate through as part of her day-to-day life.

The sources of power Beatrice and Hero appear to have in the text do not actually provide much power to them in the ShakespeaRe-told adaptated setting. For starters, their desirability does not get them much of anything, but rather proves to be more of a liability. Claude and Don's desire for Hero is a source of problems. Her desirability is also why her father is using her in the workplace. Rather than something that she is using or is getting her ahead, it is part of what draws problems to her. Beatrice is not necessarily penalized for her desirability, but many characters remark that her time is running out or that it is a shame she is alone or in other words remind her that her desirability will not be there much longer. She also does not really use it much. When she asks Benedick to act on her behalf, it is more about force of personality and sentimentality. 
Unlike in the text, Beatrice and Hero do not have the same sort of closeness. Rather than being cousins who have grown up together, Beatrice and Hero's bond stems from being the two women who have similar positions within their work. The similarity of their positions certainly seems to be the only reason Beatrice is approached to be the maid of honor at the wedding as Hero seems more friendly with the other women on the set. They hardly seem to understand each other. In one scene, Hero tries to engage Beatrice in a sort of girl talk over the wedding details and it is clear Beatrice is only half paying attention and does not seem to care. They are also talked about and seen as separate age groups and the age difference helps explain some of the difference in how the two women see each other. Beatrice is perceived as an older woman in the workplace who can be mother hen and who also can give advice. For example, while Hero will joke with other women, she wants Beatrice to approve her choice in Claudio. She will also keep Beatrice informed of wedding details and plans and chooses her to be matron/maid of honor, a twist that is played for humor based on Hero seeing Beatrice as different because she is older. Beatrice is also somewhat dismissive of Hero's interests as silly or childish. When asked to go to the bachelorette party, Beatrice complains about being mother-hen and in charge of sex toys despite being 41 . There is a respect between them, though little personal connection. They seem to be paired together because they are both women who have similar positions, but there is a clear difference between the women and the men. For example, when women suggest ideas in the workplace, they are frequently dismissed or ignored. In contrast, the men seem much more united and like they genuinely enjoy one another's company, despite the range of ages. When the men 
bring up ideas, apart from Don, they tend to bounce off each other and support one another through verbal and nonverbal means.

Most of the spaces in the film are dominated by the men. Most of the decisions in the workplace comes from the men and the workplace events. The workplace seems to take over Hero's wedding as well since the nuptials are announced in one work party and the events that continue seem to revolve around the people Hero knows from work. Even in the hotel, the women are not separate from the men. Beatrice's hotel room is joined to Benedick's by a door. Moreover, in his schemes to frame her for infidelity, Don tricks Hero into allowing him in her room. The one space in the adaptation that ends up being primarily female is Hero's bachelorette party. On camera, most of what the audience sees takes place in the women's bathroom on the night of the party where Hero and the other women from work trick Beatrice into believing Benedick is in love with her. While the space is the only one clearly defined as female, the bachelorette party is completely cut from some version of the film prepared for streaming. The version additionally changes the adaptation to imply that Beatrice has always been longing for Benedick and did not need to be tricked into realizing her feelings.

Rather than their strength coming from desirability or from unity, Beatrice and Hero's agency in the performance, seen most clearly in the ending, comes primarily from choice. Unlike a Beatrice and Hero that are dealing with family and household matters, they are primarily in their workplace. The main choice they have is whether to stay in their microculture. Typically speaking, leaving a family is more complicated than leaving a job. However, in a family, each member has more of an opportunity to change or challenge the social dynamics. In a workplace, social dynamics tend to be informed by 
the employer who has final say in who can join and who can stay. Admittingly, they each have a reason to feel a sense of loyalty for the news station. Beatrice has worked there for many years and seems otherwise isolated while Hero is Leo's daughter. Yet, they each have the clear option to walk away and get a different job.

Despite resistance to various situations coming from her coworkers, the conflicts in the story reveal that Beatrice is stuck within her microculture. Claude's humiliation of Hero strikes at her insecurities about whether a man could really love a woman. In one of the oddest moments of the production, Beatrice gives a hysterically delivered speech, similar in text to that in the play, where she wishes she were a man and could kill Claude. But, because she is not a man, she wants Benedick to do it for her. All the strength she has shown up until the wedding starts feeling hollow. The camera even zooms into Benedick's expression when she says her lines, as he is wondering if she is completely lost her mind. It comes off as a very jarring scene. She continues to yell at Benedick that when Claude insulted Hero, he "just stood there, useless," but the problem is that Beatrice was right there and she just stood there too while Claude humiliated Hero. She could have interrupted or defended Hero, but seems to think only a man could have done so. She sends Benedick to solve the problem on his own without her.

While Beatrice does not come to Hero's defense directly, Hero shows she is completely capable of facing her problem head on, drifting away from the play where Hero ends up hiding in her heart break. Hero first confronts Don demanding answers and, when a drunk Claude tries to interrupt, she shoots him down, focusing first on Don. Hero wishes to talk to Don, she comes down the stairs to confront the situation and she actually gets to silence Claude who wants to speak to her because he has realized he was in the 
wrong and he is trying to explain his actions. She confronts Don, "Because I love you and you humiliated me and I wanted you to know what that felt like," he replies. He set her up for the same reason that Claude told her off at the wedding. He felt like she humiliated him by having the power to say no, by feeling sorry for him and trying to help him. And again, in his toxic thinking, the humiliations they face are somehow equal, even though what is being done to Hero is clearly more extreme in scope. Both men claim to love her and yet feel like their actions towards her was within their rights. To them, she is not a person, but an object. Hero chooses to retaliate, slapping Don while yelling that she hates him. Don, in an instinctual attempt to subdue her, retaliates by pushing her, causing her head to crack against a wall. In the ShakespeaRe-told adaptation, she does not fake death, but is literally on the verge of dying.

While Hero spends most of the movie going along with the men in her life, the end of the movie emphasizes a shift in her viewpoint. The reason Don is able to make her look so bad is because she is trying to be kind to him: most, if not all the things he uses to convince Claude that she was unfaithful, he was able to get access to because she includes him when no one else does. He is able to make it look like she was going to spend the night with him because he knew that if he came to her claiming to miss his wife, Hero would let him into her hotel room and listen to him talk. It could not be clearer that Hero has not done anything wrong. Moreover, the ShakespeaRe-told adaptation contrasts the allegations against her with some of Hero's most admirable traits. She is accused of wrongdoing because of her need to show kindness to someone who is so clearly unhappy. Hero gets the key lines of the adaptation: "I'm so bored of people using love as an excuse. That's not love anyway, that's just possession. And I'm bored of being 
owned too, by you, by my dad... I'm just going to look after myself for a while.” Hero makes it clear that she has no intention of forgiving Claude at the end of the adaptation, encouraging him to take a job offer to go elsewhere. When he objects and claims he loves her, she replies, "Funny, that's what Don said" paralleling the two men in their claims of love. She goes on to say that love is being used as an excuse and that it is not really love, but possession. As Kidnie points out, the production does has a way of "playing with viewer expectations of the work to challenge the politics of romantic desire"(109). The audience can enjoy the healthier romance of Beatrice and Benedick, but Hero gets to move beyond the microculture. She is tired of being owned and she is going to be on her own for a time. Hero seems very happy at the ending's wedding sequence, but the comedy's twist is that instead of Hero and Claude getting married, it is only Beatrice and Benedick. Beatrice walks herself down the aisle marking her romance as a healthier one for the audience to potentially root for.

The adaptation restructures the microculture's hierarchy, alters the plot and updates the language of the script. If it were to be judged as to how close it came to the original, it would not rank well compared to other adaptations of the play. However, there is much more to gain if the film is seen instead as using the original play's themes to begin a conversation looking at gender roles in a contemporary context. The adaptation explores the relationships and agency Hero and Beatrice have within their male dominated microculture. In some of its most significant changes, it adds gender problems to the story such as Don's stalking of Hero. When Beatrice feels trapped, that limitation of power is tied to the very specific space of the workplace. The extent of the microculture's power is especially emphasized in Hero's decision to move past it. Hero 
does not really experience that feeling of being trapped by her environment openly for the audience. Instead, violent experiences push her to leave the microculture behind. Hero has determined what is best for her. In moving away from the play, the adaptation demonstrates a woman's agency to walk away from a toxic microculture. 


\section{SECTION 5: ADAPTATIONS IN COMPARISON}

Both the Joss Whedon and the BBC adaptations of Much Ado About Nothing retain the emphasis on gender found in the original play while adapting it to a contemporary setting. Staying close to the original script, Whedon retains the problematic treatment of gender in the play and, in bringing it to a contemporary setting, translates it in a commercially successful way. If anything, the sense of patriarchal constructs feels even more limiting when brought to a contemporary setting. And even though it challenges the ending found in Shakespeare's script, the BBC version also tackles these same themes in a contemporary context. Together, these two adaptations present different approaches of how gender and status within a group can be culturally approached. When put in conversation with one another, however, what becomes clear is that it is the microculture surrounding Beatrice and Hero that sets the tone for discussing power and gender. Within the contemporary setting, there is a constant sense that the microculture is not something being pushed on to Beatrice and Hero, but rather something within their social circles that they are actively contributing to. And yet, despite actively contributing to their microcultures, because these microcultures are patriarchal, they remain on the outside of the social circle. The microculture found in the text is clearly culturally powerful as it is made up of nobility and royalty. The same power is implied in the adaptations where, in Whedon's version, the characters possess a very similar status to that of the script and, in the Re-Told adaptation, the cast runs a news station which could well be of influence to its viewers. Whether the microculture is set around a family or a workplace, both adaptations provide a Beatrice and a Hero who are engaged with the 
gender problems found in the original text and that engagement is made more important because of the influence of the microcultures they belong to.

Within these conversations, there is an importance in the interpretation of Hero. The presentations of Beatrice, while in varying degrees of strength and agency, seem to be cut from the same cloth and the broad strokes behind each interpretation of the character can be clearly seen in the play. It is not so simple with Hero, as the only major broad stroke these interpretations seem to have is that she is more feminine and less outspoken than Beatrice. To some extent, the question of how Hero is interpreted comes to the degree in which these adaptations give Hero a bit more voice than in the original text. Whedon's version, working around the script, has her blocking and expressions add agency to her character by clearly showing she is interested in Claudio and by indicating her involvement in the trick that gets them married at the end of the play. Moving beyond the script, the BBC version changes Hero's arc so that a real near-death experience motivates her to move away from the men who wish to own and control her.

The differences could in part be attributed to the fact that Hero in the play's language is vaguely defined and so the differences rely on the performance. When reading the play alone, she very easily fades into the background as she rarely speaks as much as other major characters. Even some of the minor characters have more lines than she does. But when dealing with a performance rather than a written play, one must do something about the present body. Does she smile sweetly as others speak of her? Or does she appear to barely tolerate it? The text clearly defines aspects of Beatrice's wit and outspokenness, but the primary things a reader might learn of Hero are traits like 
obedience. The vagueness feeds into potential, even necessary, additional adaptation for the character.

Both adaptations connect Hero's humiliation with violence and, in a contemporary context, full violence is (thankfully) not something that is acceptable. In the Whedon adaptation, there is a tension and near violence in the blocking where it feels like violent action towards Hero, either from Claudio or her own father is just barely held back. Her seemingly mild-mannered father wishes her death over her infidelity as in the original play while shaking her. At the same time, he is no longer threatening to kill her. There is a literal violence in the BBC version where Hero's attempt to confront what has happened to her leads to her near death. The violence is caused by Don, the villain who besmirched her reputation in the first place. Especially in a contemporary setting, only the villain can be seen showing actual violence against her without additional complication. If other characters showed actual violence against Hero, it would alter the dynamics of the group as violence is not a socially acceptable way to control women.

Hero's kindness and openness, traits usually associated with lead female characters in romance, are complex. It is not perfectly clear whether kindness is exactly in the script, as scripts can be interpreted differently; it is easier to identify that she is quiet or that her behavior is socially appropriate. While there is suggestion to her sweetness and obedience, she speaks so little and does so little on her own within the text of the play, that actual shows of kindness are less certain that these other traits. She is often present in the play, but much of what can be known about Hero is learned through the comments of other characters. She has few enough lines that it is often difficult to know much about her actual personhood. Kindness might be questionable when the one 
scene where she speaks most is Act 3, Scene 1 where she criticizes Beatrice so heavily. Regardless, both productions try to get across a sweet kindness to her personality. Kindness and sweetness are frequent virtues for lead female characters, and in both adaptations, it is kindness that makes each Hero vulnerable. In Whedon's film, she is hurt by Claudio and her father precisely because of how much she loves them and the naïve belief that they are, and always will be, on her side. The Hero in the BBC adaptation is even more vulnerable as she has opened herself up to her father, Claude and Don. It is in fact because of her kindness that Don is fixated on her. None of the other women will give him time and some of the female characters show an open contempt for him. Because Hero is kind to him, especially during his divorce, he has fixated on her as his. It is not the production's commentary that there is anything wrong with Hero's kindness, but rather that someone like Don takes the kindness and feels like he can demand so much more from a woman.

Hero's relationship with her father is explored in both productions and his control over her is made clear. In Whedon's version, which sticks closer to the play, Hero herself does not even seem to question it. Even though Whedon's adaptation removes some of the harshest or most controlling lines in the play, there is still intensity in the father's reaction to Hero's alleged infidelity and Benedick holds him back from her. The amount of presence and control he still has within his daughter's life seems at odds with the visual age of the actress in a contemporary context. In the $\mathrm{BBC}$ version, Hero shows doubts at different moments and in the end pulls away. What is key, however, is that the closeness never seems to be doubted or questioned by anyone, even though, in the BBC version, Beatrice herself points out that she is knows Leo is well-aware of how men eye 
her daughter and uses it to his advantage. In addition to doing that, Leo still sees her as a little girl. There is a toxicity to the intensity of these father-daughter relationships. These are two fathers who do not see their daughters as adults, do not trust them completely and insert themselves into every facet of their lives.

At the end of each adaptation, there is a sense that she has grown. The two adaptations resolve the matter in very different ways. In Whedon's film, Hero comes across as genuinely interested in marrying Claudio. Her role in her father's schemes is presented as rather active through the shots and frames, even though there is not much corresponding dialogue. She is presented as keeping her sweetness, but with cleverness rather than naivety. In contrast, the Hero of the BBC adaptations chooses a different course. She sees that she has given too much of herself to men who are undeserving and chooses to withdraw from them as they nearly cost her life. When Claude says he loves her, she remarks that Don said the same thing. She also no longer wishes to be controlled by her father. Instead, she wants to focus on herself.

Both adaptations can give satisfaction to a contemporary audience that needs to feel she is doing what she wants to do instead of simply obeying her father's wishes as can be read in the play. If the Hero of Whedon's production chooses to forgive Claudio and marry him, it is her choice. She comes across as, while quiet, clever and as someone who genuinely enjoys being involved in schemes. It is clear she loves the people in her microculture and wishes to remain with them. Conversely, the BBC's version of Hero decides to leave her microculture and all the men within it trying to control and manipulate her. The choice each Hero faces in terms of what to do about the conflict is key to her individual power. Both are exposed to the flaws of their microculture and both 
productions present her as faced with a choice. The importance is in the act of choosing what she wants rather in what she chooses, and it is her right to do whichever option matches with her desires as an individual.

It is important that both productions sought to clarify the aspect of choice. There is no clear hint in the text that Hero still wants to be with him. In fact, after defending her maidenhood to her father following the wedding, Hero does not speak again until the next wedding. Even then, her comment points out that she once lived as he once loved, but she does not declare any such love. After that, her lines serve to reveal Beatrice truly loves Benedick. Her own real feelings are glazed over and remain a mystery. What is clear is that her marriage remains Leonardo's wish and it is the clearest route to clearing her reputation as a maiden and, in the eyes of her world, her value as a woman. While Whedon's adaptation sticks to the script, she touches his face tenderly and is later seen dancing very happily with Claudio. The blocking reassures the viewer that the marriage is what Hero genuinely wants.

In contrast, Beatrice ultimately has a crippled kind of strength. Although both adaptations and the text establish her as more vocal than Hero, is never pushed out of standing in the way that Hero experiences. The result is that when she sees the limitations of her role within the microculture, neither adapted Beatrice considers stepping out of her perceived role. Part of the issue may be that because she has agreed to be part of the microculture, she is creating part of the problem. She cannot at once rise above the group and still fit in with the group and, in both adaptations, blending with the group seems to be the side that wins over as she will not go beyond the unspoken limitations she is given. Facing these limitations feels bolder when the focus is on a character found in 
Shakespeare's time, but less so for Beatrice to fit in a contemporary plot. When looking at the past, it can feel powerful to see a female character aware of the limits society has placed around her. In the contemporary context, these limitations appear much more obvious, especially so in the $\mathrm{BBC}$ version where the microculture is based on the workplace rather than the family household. A female character who is actively doing something against these restrictions feels more powerful than one that notices the limitations and then looks to a man to act on her behalf.

Both adaptations also highlight Beatrice as more vulnerable than Benedick. While the play does imply that Benedick might have hurt her once, both adaptations begin their respective films with establishing that Beatrice and Benedick were in a relationship and that he left her. Both are guarded about love, but it certainly seems, within the context, that Beatrice has more reason to be guarded, especially when it comes to Benedick. Across all adaptations, when the other characters try to trick Benedick into loving her, they talk about how much she should be pitied for loving him so. However, when the other characters try to persuade Beatrice, they do so by criticizing her and implying that it would be ridiculous for her not to accept him if he loves her. While these reflect the respective scenes in the play, the adaptations have both pushed how far the previous relationship between Beatrice and Benedick existed. And, when the previous relationship is combined with the sort of persuasion encountered, Benedick is given the advantage in their exchanges. His only serious flaw according to the others is that he would not take Beatrice seriously and even then they are understanding as to why he might not. For Beatrice, the women know she is listening, and they criticize her flaws as they discuss Benedick's feelings for her. When they come together, Benedick has now overcome one 
of his greatest flaws in the eyes of the group, while Beatrice is only beginning to work on her own. Again, Benedick is put into the more socially advantageous position, even though both adaptations explicitly clarify that in their previous relationship, she made herself vulnerable to him and he left her. Their relationship is an aspect of the play that highlights the differences between the treatment of the genders that translates well to the contemporary era. It feels perfectly normal to manipulate a man with how vulnerable a woman is and it feels equally normal to manipulate a woman through criticism of how she is at fault. During the trick, the women are actually attempting to correct aspects of Beatrice's behavior that they find problematic. While it is not necessarily seen as a flaw that Benedick is not interested in marriage, it is a flaw in Beatrice. While marriage is not a consistent contemporary value, there is more stigma towards women who choose never to marry than men who choose the same. The group's men are understanding of Benedick's concerns with romantic vulnerability while the group's women are critical of Beatrice's expressions of the same anxiety, even though Beatrice has already been hurt by Benedick before. While it is not clear if the cast knows as much as the audience in regards to their history, there does seem to be the awareness that he left her and Beatrice herself makes reference to it in the play and in both adaptations.

Both interpretations cut Beatrice speaking on behalf of Hero. Beatrice does so multiple times within the play, but in neither production. In Whedon's version, which follows the play's script, most are cut and a few of the lines are blocked so Beatrice is checking what Hero wants rather than speaking on her behalf. In the BBC version, Beatrice would understandably never do so because they are not close enough for such a thing. Beatrice is not really a strong support for Hero and Hero must deal with problems 
on her own. Hero may not be as vocal as Beatrice in either production and is more likely to stay quiet and smile, but the plot helps separate her from Beatrice and present her as having more agency. In being pushed out of the group and in facing violence, Hero is put into a position where she must take action if she is going to find her own happiness.

It is strange that both adaptations chose to keep Beatrice wanting Benedick to commit violence on her behalf. Despite the modern setting, neither Beatrice feels like they can act to defend Hero on their own. The desire to retaliate is perfectly understandable, as is the perceived helplessness in the inability to have shielded Hero from such unfounded accusations. However, the desire to kill feels a little confusing, and her perception that only Benedick could strike back at Claudio feels strange. While the scene does show both Beatrice's limitations in power and her sympathy for Hero's plight, it fits poorly with a contemporary background. In the Whedon version, it can partially make sense in that they stuck to most of the script; however, the BBC version did not stick to the script, so it feels especially strange that the moment still occurs. Here Beatrice reacts to feeling limited within her microculture and it is significant that both adaptations include the moment where she expresses her frustration. But the more vocal she appears in the scenes preceding her speech, especially in the ShakespeaRe-Told production, the weaker she seems when she gives these lines.

In both adaptations, as in the play, it seems perfectly natural that when the humiliation befalls on Hero, Beatrice pulls away from Benedick. The anxieties and wrongs that Hero faces are real dangers to women. The issues Hero faces create a problem for other women who want a relationship with a man. While it may seem jarring that Beatrice asks Benedick to kill Claudio, it does not feel strange at all that she needs 
some sort of proof that Benedick is not like Claudio nor is he on Claudio's side. In neither production is Benedick that concerned with what has just happened to Hero as he is mostly just focused on getting with Beatrice. In the Whedon production, Beatrice literally runs from Benedick after all that has happened. The vulnerability that comes with identifying as feminine is treated as a very real thing, and it becomes difficult to be in a heterosexual relationship within the context. Especially when looking at the contrast between Claudio's humiliation and that Hero faces violence, the degrees of vulnerability are not equal. Beatrice, as a character who shares the female identity and has struggled against being vulnerable does not feel like she can continue pursuing a relationship with Benedick unless he shows beyond any doubt that he will support her in her desires.

Both contemporary versions limit the emphasis on virginity. While that remains an existing pedestal in some subcultures, it is one that society in general has moved away from especially regarding adult women. In fact, it is made clear in the Whedon production that Beatrice is not a virgin and the $\mathrm{BBC}$ production makes it clear neither Beatrice nor Hero are virgins. While there are still areas and times in contemporary circles where virginity and abstinence are expected from young women, there would be something that feels absurd in expecting all the adult single female characters of these productions to be virgins. Instead, the anxiety focuses exclusively on the question of fidelity. Interestingly, in neither production is any fault given to the men Hero potentially was paying attention to. In the Whedon version, no one seems to care who the sex was with. In the BBC version, Claudio becomes closer with John, the person Hero was supposedly unfaithful with. They seem to respond to one another as victims of an unfaithful woman. Neither production shows men facing any humiliation over the 
supposed infidelity, or even in setting her up. There are consequences for both version of Don John and, in the Whedon version, for Borachio. However, promiscuity in men is not something anyone seems to find embarrassing or humiliating, whereas most of each microculture feels humiliated by Hero even being accused of infidelity.

Age is another significant change in both productions. The ages of Beatrice and Hero as marriageable young women in Shakespeare's plays would have likely put Hero in her teenage years and, although they comment on Beatrice seems like she is likely to be a little older, but still marriageable and close enough to Hero's age to be in similar positions at social events. Clearly, such young ages would not have worked in a contemporary setting. To bring the characters into a contemporary setting, both productions brought the characters to adult women. On one hand, it is reassuring that contemporary audiences would not have accepted a story of marriages had it focused on women who were too young. On the other hand, it is not as reassuring that the gender problems faced by young women in the late 1600s would also apply to contemporary women. The same can apply to Hero's slander, Beatrice's self-perceived powerlessness, the involvement of Hero's father, the pressure on Beatrice to marry, and just about any of the scenes that translate from the play into a contemporary setting.

In a patriarchal space where women are viewed in terms of the relationships to men, it is easy to form a binary where the woman is either trustworthy or untrustworthy. As a result, Hero is one accusation away from being highly regarded in the group to being vilified. One thing both productions keep from the play is that Beatrice does not go along with the accusations. It is obvious to Beatrice that Hero's humiliation is undeserved and baseless. However, in keeping with the original piece, both versions of Beatrice are 
not able to really influence the group with their opinions. Both Beatrices show awareness of their limitations within the group and seek to act through Benedick.

A key to both adapted settings is that they are primarily made up of male dominated spaces. The scenes where Beatrice is manipulated by the other women is one of the few moments in either version, as in the original space, that seems to create a female dominated space. Having a limited female space is something that both the film and the television version explore. In Whedon's film, the scene takes place in the kitchen, a traditionally female space, and in the $\mathrm{BBC}$ version, the scene takes place in a women's restroom during a bachelorette party, another clearly feminine space. However, it should also be noted that the TV production cuts out scenes from the play where the women are all helping Hero prepare, so that the scene is the only moment in the $\mathrm{BBC}$ version where there is a female space. Additionally, some versions of the ShakespeaRe-told production cut the bachelorette party out completely creating a version of the production with no female dominated spaces. If the scene is cut, there is not much mention of tricking Beatrice, implying that all Beatrice wanted was for Benedick to show interest in her again. That means that in the ShakespeaRe-told production, Benedick always had the advantage in their interactions.

The adaptations highlight that different types of women will need to deal with the gender problems that come up in a variety of circumstances. In seeing two very different Heroes dealing with slanders and pressures against the female body, audiences can look at the gender problems from different angles. Because the text does not very specifically define Hero, the two adaptations create very different versions of the character. Although different from each other, both adapted Heroes are kind and faithful; yet both of these 
women are falsely accused of infidelity and humiliated for the alleged infidelity. The implication in both adaptions is that any female body could be susceptible to the problems pushed on these different Heroes, be it in Shakespeare's England or in the 21st century. While both Heroes deal with the brunt of the conflict, the two adapted Beatrices struggles as well. Both adaptations choose to add a scene where Beatrice is being harassed by a man they are not interested in. In the Whedon adaptation, there is a possibly drunk fellow who keeps wanting physical contact and in the ShakespeaRe-told adaptation, it is the co-worker Benedick replaces. Despite all their efforts in presenting confidence, both Beatrice characters come to feel they do not have enough power or influence within the group to defend Hero's honor. Despite differences between these four adapted women, the adaptations clearly show that they must all struggle against the male dominated world around them. However, in giving Hero the ability to resolve the conflict and pursue her own happiness, both adaptations also speak to the power of a contemporary woman to seek her happiness. 


\section{SECTION 6: FINAL CONCLUSIONS}

While the intent here is not to measure the adaptations against the original, comparing these contemporary adaptations to the original play creates a conversation about how themes are reinterpreted. Because these productions are widely different, looking at the ways they specifically intersect and diverge regarding the spaces and settings they create can create meaningful discourse. Like any of Shakespeare's plays, Much Ado About Nothing is rich in themes and in existing academic conversations. Arguably, these adaptations are complex and could be used to discuss any of the ideas within the play and its previous interpretations. When looking at how themes of women and their relationship to patriarchal power are handled, the source material becomes a useful starting point in analyzing the decisions each production made. However, when these two productions are compared to each other, there can be additional insight into how these themes adapt into the contemporary context. Hero and Beatrice certainly face gender challenges within their microculture, but they are not without power unless they choose to give that power up.

The conversion to a contemporary setting is a key component of both production and such a change necessitates certain changes. Some of the clearest changes involve the treatment of virginity and the ages of the women. Additionally, both adaptations implied Claudio and Hero were already interested in each other and the history between Beatrice and Benedick is clarifies. There is no longer a sense that Hero's engagement to Claudio is arranged, but she seems in on the decision and Beatrice no longer speaks on behalf of Hero. While there tends to be a suspension of disbelief when watching adaptations of 
Shakespeare, these details seem to be important in making the contemporary context believable enough.

One significant thing both adaptations choose to keep is the strong contrast between what is perceived as masculine and what is perceived as feminine. While in the contemporary context there is room to present something more diverse, both adaptations focus on predominantly white microcultures where gender binaries are very clearly represented. Beatrice and Hero are still desirable women in both productions. In the Whedon production, every outfit any character wears is strongly coded by gender. The BBC adaptation is a little more flexible, but most of the characters are dressed in a coded manner most of the time. The spaces and scenes tend to be dominated by the male characters including with the blocking and camera angles, which does reflect the text well. The only scene dominated by the feminine in both adaptations is the scene in which the women try to trick Beatrice into believing that Benedick is in love with her and streaming versions of the Re-Told adaptation cut the entire scene out leaving no scene taking place in a distinctly feminine space.

Primary sources of power the women have in the text is their unity, their reputation, and their desirability. The adaptations, especially the BBC adaptation, help expose the vulnerability of these sources of feminine power. In the Whedon adaptation, much like the text, these sources of power are tools of reaction rather than protection, since it is clear Hero is perfect in her behavior and still faces the conflict. They may be united, but as in the play, they must still deal with the slanders and both women feel the limitations of their power. Again, in the Whedon adaptation, they have excellent reputations, but it only takes a little effort from Don John to ruin Hero's. The desirability 
seems to make it all the more believable that Hero might have some other relationship and it causes Beatrice problems in the party scene where the man she pushes away keeps touching her. In the $\mathrm{BBC}$ version, the women are more isolated, and it is the men who are more united. Hero's reputation is still wrongfully slandered, and Beatrice's reputation is not enough for her to get as much of a voice in the workplace as she would like. Although desirability helps them have their positions in the workplace, that Beatrice and Hero's desirability can also be a source of problems that leads to both women getting attention they do not want from the men around them. These sources of power can be useful, but they are nowhere near enough to deal with the conflicts within the microcultures presented.

The presentation of Benedick and Beatrice's relationship presents something very important to the gender questions presented by both productions. They remain a man and a woman in conflict up until they are tricked into reigniting a romantic relationship with each other. A consistent theme is that no one wants to be vulnerable. While the vulnerability between these two characters get staged differently, it is emphasized in both productions. Even the underlying anxieties that the Don John characters take advantage of to slander Hero come down to questions of vulnerability. Vulnerability is something most of the major characters must deal with. And, each adaptation believably present ways in which genders can be vulnerable to each other within the patriarchal structure.

The contemporary context explores the limitations of Beatrice's power. In trying to be part of her microculture, she limits her own power. It is not a healthy place for her to be. Both adaptations include having Hero and the other women put her down for being the sort of woman who would reject Benedick. Both adaptations also include the scene 
where Benedick, believing she is interested in him, cannot understand that she is not interested in him. Nowhere is her lack of power clearer than when she repeats the speech criticizing masculinity and wishing she were a man. For all the perceived strength in how she talks with the men, Beatrice feels she cannot do anything to protect Hero. While the speech feels out of place in a contemporary context, both adaptations have Beatrice deliver the lines in a desperate manner. The delivery might indicate that she is so far within the patriarchy her microculture that she cannot imagine acting outside its perceived bounds. The implication of delivering these lines indicate that the idea of what a man and what a woman are and can do are very strongly defined when, again in the contemporary context, there are other ways of understanding gender identity. While she seems to maneuver through the male-dominated spaces more easily than Hero, it comes at the cost of being unable to step out.

The adaptations help point out that while Hero is less vocal than Beatrice, she is pushed further, and that push leads her to take action. Hero is not simply less aggressive than Beatrice. While both adaptations show a Beatrice that is mostly doing what she wants to do, the Don John characters are trying to use Hero as a pawn, the Claudio characters are trying to possess her and the Leonato characters are trying to control her as part of their own reputation. While the two adaptations present very different versions of Hero, they both respond to their fathers kindly and graciously, maintaining an image of a young woman that can be seen as proper within her microculture and meet their father's approval. And yet, no matter how perfect Hero tries to be, just having the ability to not meet the group's expectations makes the men in her life vulnerable. Slander without substantial evidence leads to violence and potential death. No other character is pushed so 
hard or stands to lose nearly as much, and yet Hero is in her situation because of what the other characters perceive they could lose because of her. Pushed so hard, both adaptations show Hero having a real sort of power over her outcome: she gets to decide what she wants. Although both adaptations have very different endings, they both choose to give her a choice in going after what she wants at the end of her struggle. In the play, reconciliation with Claudio is something her father and the friar decide on and plot out while Hero herself has no line in the text to indicate whether she wants the marriage. Her personal desires are in no way clarified. In Whedon's adaptation, Hero may have the same lines, but it includes a scene where Hero smiles sadly while watching Claudio mourn her from above and she later delivers the lines in which she reveals herself, lovingly with blocking of her gently cupping his face as he reacts. In the Re-Told adaptation, Hero acts and makes decisions entirely on her own. Both adaptations make it completely clear that Hero is making the choice she wants.

The real source of power presented in both adaptations is agency. The Beatrice characters, in trying to be a successful part of the group, either give up or are so far in they do not realize they have the ability to make a real choice about how the microculture is working. Both adaptations create microcultures that are flawed and patriarchal. However, as members of the microculture, Hero and Beatrice do have a say, even if the men are the ones dominating the conversation. When they choose to let things continue the way they are, they are part of crafting that microculture. The adaptations highlight Hero as the character that, because of the problems she has to face, sees the clear problem in the microculture she is a part of and takes hold of real power: taking action towards the goal she desires. Beatrice sees the flaws as well, but perhaps because she is not the one 
pushed out of favor with the group, both adapted versions despise their social boundaries but do not seem to even consider life beyond them. On the other hand, Hero faces violence and is pushed out of the group without having done anything wrong. By being pushed out as an adult, she has to decide if she wants to rejoin the group or not, and when she does rejoin in the Whedon adaptation, the adaptation clarifies her willingness rather than just obedience to her father. Like in the play, both adaptations have a happy ending for most of the group and the happiness of that ending has much to do specifically with Hero's actions. While both versions of Beatrice support Hero, both versions of Hero show willingness to face the problems and to face those problems in a way that leads to their own personal happiness rather than simply redeeming Claudio or Leonato's reputation. The Hero in Whedon's adaptation is in love with Claudio and confirms that he still loves her before reconciling. In the Re-Told adaptation, Hero confronts her accusers straight away and decides that between her experiences with Don, Leo and Claude, that it is time for her to leave and find something else.

In the text and in both adaptations, the stress of trying to upkeep a patriarchal society harms everyone involved. All three depict a man's world and all the problems the characters, regardless of whether they are male or female, must deal with stem from the pressures of maintaining that standard. And yet, despite the changes in the times, patriarchy is something that encourages self-replication. Moreover, these attempts at establishing power are still very believable in a contemporary context, even if most people cannot directly relate to a prince trying to further a patriarchal lineage. All versions of Beatrice and Hero struggle to wade through these problematic structures. It would be an exaggeration to assume that the exact same gender practices in the time of 
Shakespeare would be entirely acceptable today; however, what the adaptations show is that Beatrice and Hero are active parts of their microculture. Whether Hero chooses to stay and try to make things better or whether she chooses to walk away, she has a say in how to face the problems of the world she grew up in. Together, the adaptations create an image of women wading through a man's world and experiencing difficulties and limitations simply based on the fact that they were born women; but, these adaptations also emphasize that women have the ability to shape the group around them making them better and walking away from their own specific microcultures when the patriarchal influences prove to be toxic. The adaptations show a Hero who chooses to go after her desired ending for the story.

The way these two productions present Shakespeare's play showcases that many, though not all, of the gender themes and problems can still translate into a contemporary setting. Analysis that focuses on aspects of adaptation, beyond the fidelity discussions that used to be prevalent, is important because, as Desmet argues, "reconsidering appropriation as reception rather than as production therefore connects texts across times and space, establishing... insight to put these texts into a different perspective" (55). Together, these two adaptations are meaningful, not because they are perfect representations of the original play, but because in adapting the play to a contemporary setting, these adaptations present the possibility of a new perspective on the adapted themes. By examining these contemporary adaptations through the specific lens of how they handle female representation, we can create more dialogue with the themes through those new perspectives. By studying these film productions, an audience can see the potential destruction patriarchal structures can create within smaller groups of people. 
The study of contemporary adaptations which bring material, such as Shakespeare, into contemporary settings is very valuable. Such adaptations are marketable, and it is likely there will be more such adaptations in the future. Not only are they more approachable to audiences, but they have a potential to bring new perspectives like those that Desmet suggests. These adaptations with contemporary settings also create many opportunities for analysis. There are creative choices that must be considered in changing sets, costumes and some details that would not be successful in a contemporary setting. These types of stories bring the source material's themes in direct conversation with the contemporary audience.

Rather than being a study of general contemporary culture, these adaptations of Much Ado About Nothing are significant for their examination of a contemporary microculture. As the study of adaptation moves away from a discussion on fidelity, adaptations that bring older material into a contemporary setting can be a rich source of analysis, especially when a story has been adapted more than once. Huang and Rivlin argue that "to scrutinize the communities a new appropriation builds, as well as what or who is excluded from them, is to keep our sights trained on the broader human stakes" (17). When looking specifically to Hero and Beatrice as representative of the feminine in the play, there are certainly limitations they must face within their groups. Aspects of patriarchy may vary from group to group, but while Beatrice and Hero can perceive themselves as trapped and powerless, they do not have to be. Their decisions help form the group around them and, in the end, they have the power to try to fix things or to walk away. Such representations are important even if they only represent similar contemporary women in similar microcultures rather than contemporary women as a 
whole. The representation of their power is significant not only because they were adapted as having that agency, but also because that change can be made in a contemporary setting. And, in that study of "the broader human stakes," analyzing the deliberate decisions made to adapt Much Ado into these contemporary settings is far more productive than measuring them based on their fidelity to the original text. 


\section{BIBLIOGRAPHY}

Bamber, Linda. Comic Women, Tragic Men. Stanford: Stanford University Press, 1982.

Butler, Judith. Gender Trouble: feminism and the subversion of identity. New York: Routledge, 1999.

Desmet, Christy and Sujata Iyengar. "Adaptation, appropriation, or what you will." Shakespeare (2015): 10-19.

Desmet, Christy. "Recognizing Shakespeare, Rethinking Fidelity: A Rhetoric and Ethics of Appropriation." Shakespeare and the Ethics of Appropriation. Ed. Alexa Huang and Elizabeth Rivlin. New York: Palgrave MacMillan, 2014. 41-57.

Erickson, Peter. Patriarchal Structures in Shakespeare's Drama. Berkeley: University of California Press, 1985.

Harvey, Sara M. Shakespeare, Feminism, and Joss Whedon. March 2014. <http://saramharvey.com/reblogs/shakespeare-feminism-and-joss-whedon/>.

Harvey, Sara. Shakespeare, Feminism, and Joss Whedon. 2 September 2015.

Hays, Janice. "Those "soft and delicate desires": Much Ado and the Distruct of Women." Swift Lenz, Carolyn Ruth, Gayle Greene and Carol Thomas Neely. The Woman's Part: Feminist Criticism of Shakespeare. University of Illinois Press, 1980. 79-99.

Huang, Alexa and Elizabeth Rivlin. "Shakespeare and the Ethics of Appropriation." Shakespeare and the Ethics of Appropriation. Ed. Alexa Huang and Elizabeth Rivlin. New York: Palgrave Macmillan, 2014. 1-20.

Jagger, Gill. Judith Butler: sexual politics, social change and the power of the performative. New York: Routledge, 2008.

Jankowski, Theodora A. "...In the Lesbian Void: Woman-Woman Eroticism in Shakespeare's Plays." Callaghan, Dympna. A Feminist Companion to Shakespeare. Malden: Blackwell Publishers, 2000. 299-319.

Kaplan, E. Ann. Women \& Film: Both Sides of the Camera. New York: Methuen \& Co., 1983.

Kidnie, Margaret Jane. Shakespeare and the Problem of Adaptation. New York: Routledge, 2009.

Kirby, Vicki. Judith Butler: Live Theory. New York: Continuum International Publishing Group, 2006. 
Lanier, Douglas. "'Good Lord, for alliance" : Joss Whedon's Much Ado About Nothing." Représentations: La revue électronique du CEMBRA (2014): 117-142.

—. "Recent Shakespeare adaptation and the mutations of cultural capital." Shakespeare Studies (2010): 104-113.

Lanier, Douglas. "Shakespearean Rhizomatics: Adaptation, Ethics, Value." Shakespeare and the Ethics of Appropriation. Ed. Alexa Huang and Elizabeth Rivlin. New York: Palgrave Macmillan, 2014. 21-40.

Lloyd, Moya. Judith Butler: From Norms to Politics. Malden: polity, 2007.

Mahony, Blair. "Screwball Shakespeare: Much Ado About Nothing." Screen Edition (2014): 116-120.

McEachern, Claire. "Fathering Herself: A Source Study of Shakespeare's Feminism." Shakespeare Quarterly (1988): 269-290.

Milestone, Katie and Anneke Meyer. Gender \& Popular Culture. Malden: Polity Press, 2012.

Much Ado About Nothing. Dir. Joss Whedon. 2013. DVD.

Park, Clara Claiborne. "As We Like It: How a Girl Can Be Smart and Still Popular." Swift Lenz, Carolyn Ruth, Gayle Greene and Carol Thomas Neely. The Woman's Part: Feminist Criticism of Shakespeare. University of Illinois Press, 1980. 100116.

Salih, Sara. Judith Butler. New York: Routledge, 2002.

Scott, A. O. "Arguing Their Way Into Love." The New York Times 6 June 2013. 4 June 2020. <https://www.nytimes.com/2013/06/07/movies/much-ado-about-nothingdirected-by-joss-whedon.html $>$.

Scott, A.O. Movie Review: Arguing Ther Way Into Love. 6 June 2013. <https://www.nytimes.com/2013/06/07/movies/much-ado-about-nothingdirected-by-joss-whedon.html>.

Shakespeare, William. Folger Shakespeare Library: Much Ado About Nothing. New York: Simon \& Schuster Paperbacks, 1995.

ShakespeaRe-Told: Much Ado About Nothing. Dir. Brin Percival. 2005. 
Suzuki, Mihoko. "Gender, Class, and the Ideology of the Comic Form: Much Ado About Nothing and Twelfth Night." Callaghan, Dympna. A Feminist Comapnion to Shakespeare. Malden: Blackwell Publishers, 2000. 121-143.

The Candle Wasters. Nothing Much to Do. 2014. Youtube Series. <https://www.youtube.com/watch?v=Rn57zw4--D0>.

Thornham, Sue. Feminist Film Theory: A Reader. Edinburgh: Edinburgh University Press, 1999. 